\title{
Impacts of two types of La Niña on the NAO during boreal winter
}

\author{
Wenjun Zhang $\cdot$ Lei Wang $\cdot$ Baoqiang Xiang $\cdot$ \\ Li Qi · Jinhai He
}

Received: 12 October 2013/Accepted: 17 April 2014/Published online: 4 May 2014

(C) The Author(s) 2014. This article is published with open access at Springerlink.com

\begin{abstract}
The present work identifies two types of La Niña based on the spatial distribution of sea surface temperature (SST) anomaly. In contrast to the eastern Pacific (EP) La Niña event, a new type of La Niña (central Pacific, or CP La Niña) is featured by the SST cooling center over the CP. These two types of La Niña exhibit a fundamental difference in SST anomaly evolution: the EP La Niña shows a westward propagation feature while the $\mathrm{CP} \mathrm{La}$ Niña exhibits a standing feature over the CP. The two types of La Niña can give rise to a significantly different teleconnection around the globe. As a response to the EP La Niña, the North Atlantic (NA)-Western European (WE) region experiences the atmospheric anomaly resembling a negative North Atlantic Oscillation (NAO) pattern accompanied by a weakening Atlantic jet. It leads to a cooler and drier than normal winter over Western Europe. However, the CP La Niña has a roughly opposing impact on the NA-WE climate. A positive NAO-like climate anomaly is observed with a strengthening Atlantic jet, and there appears a warmer and wetter than normal winter over
\end{abstract}

W. Zhang $(\bowtie) \cdot$ L. Wang $\cdot$ L. Qi $\cdot$ J. He

Collaborative Innovation Center on Forecast and Evaluation of Meteorological Disasters, Key Laboratory of Meteorological Disaster of Ministry of Education, Nanjing University of Information Science and Technology, Nanjing 210044, China e-mail: zhangwj@nuist.edu.cn

\section{W. Zhang}

Key Laboratory of Numerical Modeling for Atmospheric Sciences and Geophysical Fluid Dynamics, Institute of Atmospheric Physics, Chinese Academy of Sciences, Beijing 100029, China

B. Xiang

International Pacific Research Center, University of Hawaii at Manoa, Honolulu, HI 96822, USA
Western Europe. Modeling experiments indicate that the above contrasting atmospheric anomalies are mainly attributed to the different SST cooling patterns for the two types of La Niña. Mixing up their signals would lead to difficulty in seasonal prediction of regional climate. Since the La Niña-related SST anomaly is clearly observed during the developing autumn, the associated winter climate anomalies over Western Europe could be predicted a season in advance.

Keywords Two types of La Nina - Climate impacts . The North Atlantic and Western Europe

\section{Introduction}

The El Niño-Southern Oscillation (ENSO) represents a periodic fluctuation between warm (El Niño) and cold (La Niña) conditions in sea surface temperature (SST) over the central to eastern tropical Pacific (Philander 1990; McPhaden et al. 2006). As one of the most important coupled ocean-atmosphere phenomenon, the ENSO has received extensive public attention because of its profound global climate impacts (e.g., van Loon and Madden 1981; Ropelewski and Halpert 1987, 1996; Trenberth and Caron 2000). By now, the linkage between ENSO and the climate in the North Pacific and North America has been well understood and is usually referred to as the "Pacific-North America" (PNA) teleconnection (e.g., Wallace and Gutzler 1981; Branston and Livezey 1987). However, climate responses to ENSO over the North Atlantic (NA)-Western European (WE) sector are controversial.

In the 1980 s and early 1990s, early studies showed that ENSO-related precipitation and temperature anomalies are 
almost absent over the NA-WE region (Ropelewski and Halpert 1987; Halpert and Ropelewski 1992). The viewpoint is supported by later studies that the climate signal of ENSO over the NA-WE sector is difficult to be detected because of the large inter-event variability (see an extensive review by Brönnimann 2007). This non-stationary behavior is possibly due to some modulating factors, such as the complexity of ENSO itself (Greatbatch et al. 2004), natural (or internal) variability in the extratropical circulation (Kumar and Hoerling 1998), tropical volcanic eruptions (Brönnimann et al. 2007a), and other climate signals independent of ENSO (e.g., Mathieu et al. 2004; Garfinkel and Hartmann 2010). Nevertheless, the argument of the absence of ENSO signal over the NA-WE region was challenged by numerous studies (e.g., Brönnimann et al. 2007b; Ineson and Scaife 2009; Li and Lau 2012). These studies argued that a significant ENSO signal is found over the region of Europe despite the large interevent variability. A canonical El Niño response in late winter is suggested to be accompanied by a negative North Atlantic Oscillation (NAO)-like pattern with a colder and drier than normal weather, and the La Niña has a largely opposing impact (e.g., Gouirand and Moron 2003; Brönnimann et al. 2007b). In comparison, the NA atmospheric response to La Niña is found to be much more stable than that due to El Niño during winter (Pozo-Vázquez et al. 2005). Since the NA atmosphere shows higher predictability associated with the La Niña compared to the El Niño, our focus of this study is on the NA-WE atmospheric response associated with La Niña events.

Recent studies argued that a new type (or flavor) of El Niño, in addition to the conventional El Niño, occurs more frequently in the recent decades with its maximum center over the central equatorial Pacific rather than the eastern Pacific (EP) (Larkin and Harrison 2005; Ashok et al. 2007; Kao and Yu 2009; Kug et al. 2009; Yeh et al. 2009; Ren and Jin 2011; Wang and Wang 2013). In particular, the new type of El Niño becomes the dominant mode after the late 1990s (Xiang et al. 2013). For convenience, EP and CP El Niños are referred to as the conventional and the new type of El Niño herein, respectively. Many studies have reported the importance of the $\mathrm{CP}$ El Niño in terms of its distinctly different climate impacts from the EP El Niño (Weng et al. 2007; Taschetto and England 2009; Feng et al. 2010; Feng and Li 2011, 2013; Lee et al. 2010; Zhang et al. 2011, 2012, 2013; Xie et al. 2012; Yu et al. 2012; Afzaal et al. 2013).

The La Niña diversity is also concerned in its impact on extratropical atmosphere, such as over East Asia (e.g., Wang et al. 2012). At present, there appears a scientific consensus on the occurrence of the new type of El Niño, however, whether La Niña events can be separated into two types remains open to debate. Some studies suggested that the zonal location of the maximum SST anomaly center does not show apparent change for individual La Niña event (Kug et al. 2009; Kug and Ham 2011; Ren and Jin 2011). On the contrary, some other studies argued for the existence of two types of La Niña (e.g., Cai and Cowan 2009; Shinoda et al. 2013). For example, the CP La Niña is argued to be clearly distinguished from the EP La Niña events in terms of ocean surface currents through analyzing recent satellite data (Shinoda et al. 2013). So far, the fundamental dynamics is not well understood that is used to explain differences in the generation and maintenance of two types of ENSO. Given unclear dynamical mechanisms, one possible way to distinguishing them is to investigate the associated local circulation and extratropical teleconnections. The analyses performed in this paper show that the winter atmospheric anomalies over the NA-WE region are very different from each other for these two types of La Niña. The result, on the one hand, will provide a possible indirect evidence for the existence of different flavors of $\mathrm{La}$ Niña. On the other hand, the necessity is emphasized to separate the La Niña events into two types when analyzing their associated extratropical climate impacts. Mixing up their signals would increase difficulty in seasonal prediction of the climate particularly over the NA-WE sector.

The purpose of the study is to explore the different teleconnection patterns and their associated climate anomalies over the NA-WE sector for the two types of $\mathrm{La}$ Niña. In the remainder of the paper, Sect. 2 describes data, methodology, and model experiments. Section 3 illustrates SST anomaly patterns for the two types of La Niña and its associated atmospheric responses over the tropical Pacific. Section 4 presents atmospheric responses over the NA-WE region. In Sect. 5, we explore possible mechanisms for the climate impacts on influencing the NA-WE climate associated with the two types of La Niña. Section 6 discusses asymmetry in influences of ENSO on the NA-WE climate. The major conclusions are summarized in Sect. 7.

\section{Data and methodology}

\subsection{Observations}

The monthly SST datasets (1951-2009) used in this study are the global sea ice and SST analyses from the Hadley Centre (HadISST1) provided by the Met Office Hadley Centre (Rayner et al. 2003). Atmospheric circulations were examined based on the National Centers for Environmental Prediction/National Center for Atmospheric Research (NCEP/NCAR) reanalysis data (Kalnay et al. 1996). The precipitation data are taken from the Climate Prediction Center Merged Analysis of Precipitation (CMAP) (1979-2009) (Xie and Arkin 1996) and the Global 
Precipitation Climatology Centre (GPCC) (1951-2009) (Rudolf et al. 2005). The surface temperature anomalies over WE are investigated using the Climate Research Unit (CRU) air temperature anomalies version 4 (CRUTEM4) (1951-2009) (Jones et al. 2012). Anomalies for all variables were conducted as the deviation from the 30-year climatological mean (1961-1990). The 1971-2000 average can also be defined as the climate mean, which does not influence qualitative results. The average over the entire period (1979-2009) is taken as the climate mean for the CMAP precipitation because the data are available after 1979. In order to remove possible influence associated with the long-term trend, all anomalies are linearly detrended over the period 1951-2009, except for the CMAP data over the period 1979-2009. The non-detrended data are also examined and the results are almost the same. Composite and regression analyses are employed to investigate differences in climatic impact associated with the two types of La Niña, using Student's two-tailed significance test.

\subsection{Definition of two types of La Niña events}

Unlike contrasting SST anomaly patterns associated with the two types of El Niño, Ren and Jin (2011) suggested that the La Niña events seem to be difficult to be clearly separated into two types based on their index. Based on the DJF (December-February) mean ENSO and ENSO Modoki indices (Ashok et al. 2007), half of events selected are the same in the two types of La Niña (Tedeschi et al. 2012). It is also expected that the two types of La Niña events cannot be well distinguished based on the index defined by Kao and Yu (2009), since the current indices of the twotype ENSO show high consistency (Ren and Jin 2013). Considering the fact that the present ENSO indices cannot effectively distinguish the two types of La Niña events, we therefore identify the selection by an analysis of the spatial distribution of SST anomaly patterns. First, 17 La Niña winters are defined by the Climate Prediction Center (CPC) over the period 1951-2009 based on a threshold of $-0.5^{\circ} \mathrm{C}$ for winter (DJF) mean Niño3.4 $\left(5^{\circ} \mathrm{S}-5^{\circ} \mathrm{N}, 120^{\circ}-\right.$ $\left.170^{\circ} \mathrm{W}\right) \mathrm{SST}$ anomaly. Then we identify seven EP La Niña winters $(1954 / 55,1955 / 56,1964 / 65,1971 / 72,1984 / 85$, 1995/96, and 2005/06) and seven CP La Niña winters (1973/74, 1974/75, 1975/76, 1983/84, 1988/89, 1998/99, and 2000/01). The winters, having larger SST anomaly in the EP (CP) east (west) of $150^{\circ} \mathrm{W}$ during the developing and mature phases of La Niña, are classified into the EP (CP) La Niña winters. The longitude of $150^{\circ} \mathrm{W}$ is selected because it is a boundary of Niño3 $\left(5^{\circ} \mathrm{S}-5^{\circ} \mathrm{N}, 150^{\circ}-90^{\circ} \mathrm{W}\right)$ and Niño4 $\left(5^{\circ} \mathrm{S}-5^{\circ} \mathrm{N}, 160^{\circ} \mathrm{E}-150^{\circ} \mathrm{W}\right)$ areas, which are usually used to define the two-type ENSO events (e.g., Kim et al. 2009; Kug et al. 2009). Other three years (1970/71, 1999/00, and 2007/08) are defined as the mixed type of La
Niña, because the large cooling SST anomaly covers both the EP and CP during the mature phase. Their characteristics will be further discussed in Sect. 3. The year listed here corresponds to year(0)/year(1). The developing year of the La Niña event and the following year is designated as year(0) and year(1), respectively. A typical ENSO tends to develop during the spring season and lasts for roughly a year. However, long-lasting La Niña events are often observed, such as the events for 1954-56 and 1973-76 selected in this study. After excluding these events, the qualitative difference influencing conclusions is not detected.

\subsection{Simulations}

All model simulations are performed using the National Center for Atmospheric Research (NCAR) Community Atmospheric Model Version 5 (CAM5) (Neale et al. 2010). CAM5 has been updated in many physical processes compared to the previous version. The version has a finite volume dynamic core with resolution of $1.9^{\circ}$ longitude $\times 2.5^{\circ}$ latitude and 30 vertical levels. In the control run (CNTRL), CAM5 is driven by climatological (seasonal varying) SST and the results were derived as a reference state. A series of sensitive experiments listed in Table 1 were performed to compare the climate impacts of different SST anomaly patterns associated with the two types of La Niña. In the first simulation (EP cooling, EP_COOL), the cold SST anomaly during the EP La Niña winter is imposed on the monthly climatological SST from October to February in the tropical Pacific $\left(30^{\circ} \mathrm{S}-30^{\circ} \mathrm{N}, 120^{\circ} \mathrm{E}-\right.$ $90^{\circ} \mathrm{W}$ ). All anomalies outside of the region are set to zero. The second experiment (CP cooling, $\mathrm{CP} \_\mathrm{COOL}$ ) designed is the same as the EP_COOL experiment, expect that the SST anomaly is the composition during the CP La Niña winter. The third experiment ( $\mathrm{CP}$ warming, $\mathrm{CP}_{-}$WARM) is

Table 1 List of SST perturbation experiments conducted in this study

\begin{tabular}{ll}
\hline Expt & Description of SST perturbation \\
\hline EP_COOL & $\begin{array}{c}\text { Cooling anomalies associated with EP La Niña } \\
\text { events imposed in the tropical Pacific }\left(30^{\circ} \mathrm{S}-30^{\circ} \mathrm{N},\right. \\
\left.120^{\circ} \mathrm{E}-90^{\circ} \mathrm{W}\right)\end{array}$ \\
CP_COOL & As in EP_COOL but for the CP La Niña events \\
CP_WARM & $\begin{array}{c}\text { As in CP_COOL but for warming anomalies in the } \\
\text { tropical Pacific }\left(30^{\circ} \mathrm{S}-30^{\circ} \mathrm{N}, 120^{\circ} \mathrm{E}-120^{\circ} \mathrm{W}\right)\end{array}$ \\
CP_CW & CP_COOL cooling and CP_WARM warming \\
& anomalies imposed together \\
AT_COOL & As in CP_COOL but for cooling anomalies in the \\
& northern tropical Atlantic Ocean $\left(10^{\circ} \mathrm{S}-25^{\circ} \mathrm{N}, 0^{\circ}-\right.$ \\
& $\left.80^{\circ} \mathrm{W}\right)$ \\
CPAT_COOL & CP_COOL and AT_COOL cooling anomalies \\
& imposed together
\end{tabular}


also the same as the EP_COOL and CP_COOL experiments, but the warming SST anomaly during the CP La Niña winter is added to the seasonally varying monthly climatological SST over the western tropical Pacific. In this experiment, we consider the possible impacts of the warming SST anomaly, since the positive SST anomaly appears significantly over the western tropical Pacific during the CP La Niña winter. In the fourth experiment (CP cooling and warming, CP_CW), we conduct sensitivity simulations where the CP_COOL and CP_WARM forcings are imposed together to inspect the combined contribution of the warming and cooling SST anomaly over the tropical Pacific during the CP La Niña winter. We also study possible effects of the cooling SST anomalies in the northern tropical Atlantic Ocean during the CP La Niña winter in the fifth experiment (Atlantic cooling, AT_COOL), since the significant cooling SST anomalies occur there. In the last experiment ( $\mathrm{CP}$ and Atlantic cooling, CPAT_COOL), the CP_COOL and AT_COOL forcings are both imposed to examine their combined impacts on atmosphere. All simulations are integrated for 15 years and the last 10 years' integration was considered to exclude influence of the initial condition and the internal variability.

\section{SST anomaly pattern and its associated atmospheric response over the tropical Pacific}

Figure 1 displays the seasonal evolution of the equatorial $\left(5^{\circ} \mathrm{S}-5^{\circ} \mathrm{N}\right)$ SST anomaly for the above mentioned three types of La Niña. The evolution of the EP La Niña is similar to the conventional La Niña event (Fig. 1a) with its SST anomaly developing in the far EP and reaching its largest amplitude during November(0) and December(0). The evolution of the maximum centers indicated by marked crosses shows that the EP La Niña-SST anomaly propagates westward at a certain speed. During the developing and mature phase, the EP La Niña is manifested by larger cooling SST anomaly mainly confined in the eastern equatorial Pacific east of $150^{\circ} \mathrm{W}$. In contrast to the EP La Niña, the CP La Niña exhibits a fundamental difference in the SST anomaly structure and its evolution (Fig. 1b). Firstly, its action center is shifted westward into the central equatorial Pacific. Secondly, the SST anomaly almost does not propagate for the CP La Niña, representing a standing feature. The CP La Niña seems to be mainly associated with the local air-sea interaction that develops and decays in situ over the CP. As the CP La Niña develops, its SST anomaly also extends eastward and westward from the CP. Contrasting features of SST anomaly evolution associated with the EP and CP La Niña suggest that their underlying dynamics should be different, which provides a possible evidence for the existence of different types of La Niña. Such discussion has been given, for example, previous studies argued that the thermocline dynamics, as the most important dynamics for traditional (or EP) ENSO, seems to play a less important role on the CP ENSO (e.g., Kao and Yu 2009). For the mixed type of La Niña (Fig. 1c), the SST anomaly center starts in the EP, and shifts slightly eastward in the developing phase. During the mature phase, the SST anomaly center propagates rapidly from the EP to the $\mathrm{CP}$. The large negative SST anomaly stretches across the EP and CP during the mixed type of La Niña winter, mixing the SST anomalies associated with the EP and CP La Niña (not shown).

To further investigate the phase locking of La Niña, we use Niño3, Niño4, and Niño3.4 SST anomaly to denote the EP, CP, and mixed type, respectively. As shown in Fig. 2, the EP and CP La Niña events exhibit an approximate feature during the developing phase. Both types of events reach the maximum around December(0) with almost the same intensity. After December(0), the CP La Niña enters a slower decay phase than the EP La Niña. For the mixed type of La Niña, it is characterized by much larger amplitude and the delayed occurrence of the mature phase by a month compared to the EP and CP La Niña. Again, the mixed type of La Niña exhibits its distinct feature and it seems necessary to classify them into a single group. Since the action center of the mixed-type La Niña covers the EP and $\mathrm{CP}$ as shown in Fig. 1, it may mix signals of the EP and CP La Niña in terms of the extratropical atmospheric response. In this paper, the contrasting climate impacts of the EP and CP La Niña over the NA-WE sector are our focus, so the mixed type of La Niña will not be discussed in the remainder of the paper.

Figure 3 shows the composite SST and surface wind anomalies during EP and CP La Niña winters. During boreal winter, the SST anomaly for the EP La Niña covers the $\mathrm{CP}$ and $\mathrm{EP}$ with the maximum center occurring in the EP. Almost no significant warming SST anomaly is found over other domain of the tropical Pacific. As a Rossby wave response (Gill 1980) to the cooling SST anomaly, a pair of anticyclone anomalies resides at each side of the central equatorial Pacific accompanying by easterly wind anomaly at the equator. In contrast, the cooling center of SST anomaly associated with the CP La Niña is displaced westward into the central equatorial Pacific west of $150^{\circ} \mathrm{W}$ with a weak SST anomaly in the far eastern equatorial Pacific. As shown in Fig. 3, the amplitude of the CP La Niña appears to be stronger than that of the EP La Niña, with significant warming SST anomaly occurring in the northwestern and southwestern tropical Pacific. The weaker amplitude of the EP La Niña is possibly associated with the faster decaying rate in its SST anomaly (Fig. 2). In comparison with the surface wind response to the EP La Niña, the pair of anticyclone anomalies occurring at both 
(a)

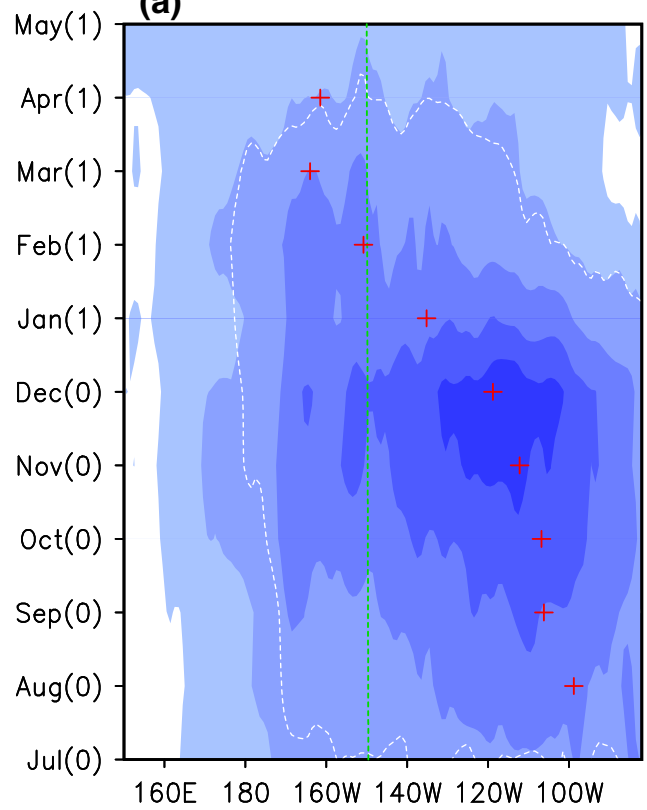

(b)

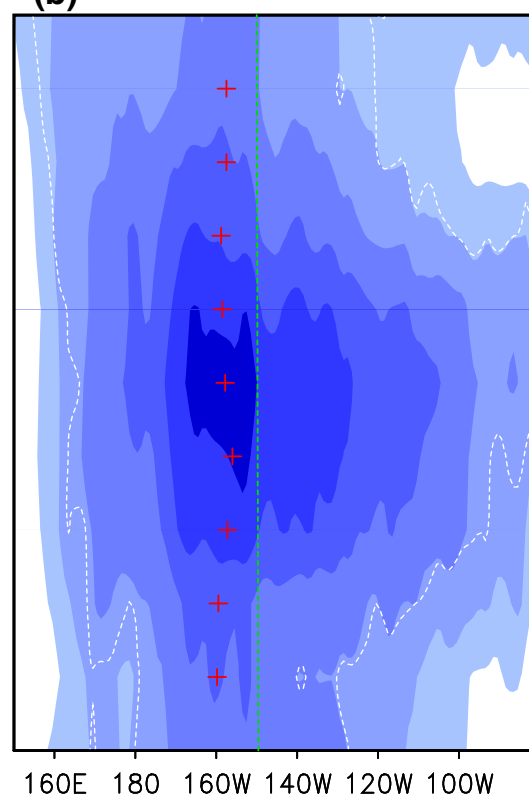

(c)

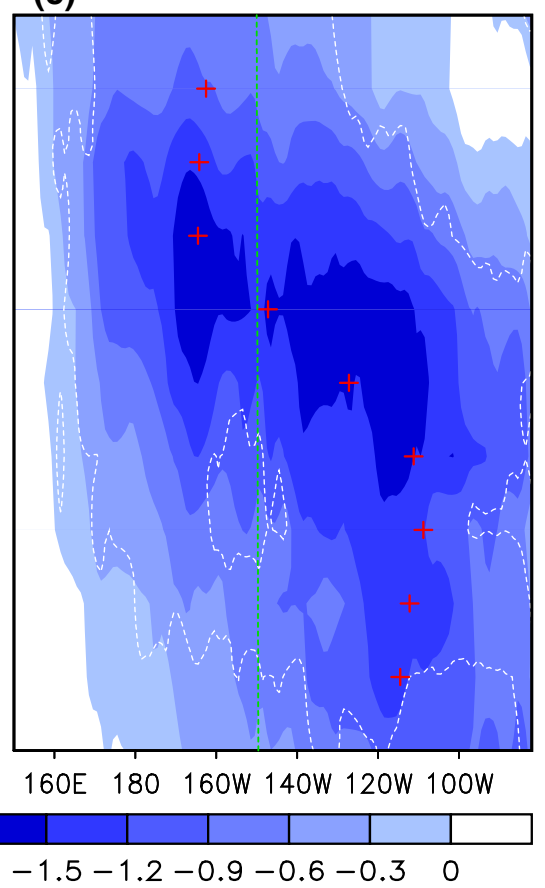

Fig. 1 Time-longitude diagram of SST anomaly $\left({ }^{\circ} \mathrm{C}\right)$ composites in the equatorial Pacific $\left(5^{\circ} \mathrm{S}-5^{\circ} \mathrm{N}\right)$ for a EP La Niña, b CP La Niña, and c mixed La Niña. The ordinate presents an 11-month period from July of year 0 to May of year 1. Contour lines indicate values that are

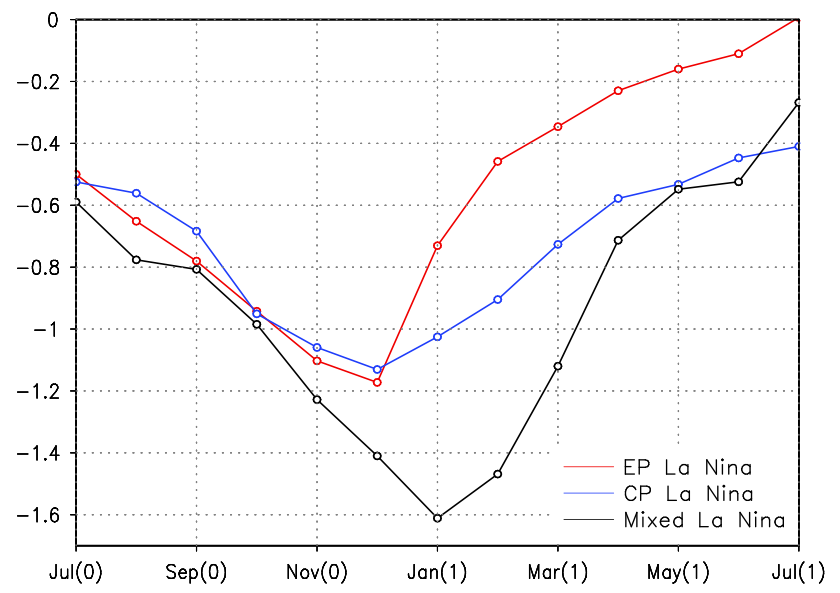

Fig. 2 Composite monthly evolution of the Niño3 SST anomalies $\left({ }^{\circ} \mathrm{C}\right)$ for the EP La Niña (red curve), the Niño4 SST anomalies for the CP La Niña (blue curve), and Niño3.4 SST anomalies for the mixed La Niña (black curve). The abscissa indicates a 13-month period from July of year 0 to July of year 1

sides of the equator also shifts relatively westward into the western tropical Pacific (Fig. 3b). It is notable that westerly anomaly occurring over the far eastern equatorial Pacific that is not observed in the EP La Niña composition could inhibit the cooling upwelling and thus weaken the SST anomaly there. significant at the $95 \%$ confidence level. Red crosses mark the longitudes of the maximum SST anomalies which are smoothed spatially using a 3-point running mean

The tropical convection anomalies associated with the two types of La Niña are expected to be distinct due to their differing SST anomaly patterns (Fig. 4). Because precipitation data over the tropical ocean are available since the late 1970s, the divergence of water vapor (integrated from surface to $300 \mathrm{hPa}$ ) is examined here to roughly reflect the precipitation anomaly based on the balance equation of the atmospheric water vapor (Yanai et al. 1973). Corresponding to the EP La Niña, the associated convective anomaly center emerges mainly over the $\mathrm{CP}$ to the west of the negative SST anomaly center (Fig. 4a). Enhanced precipitation indicated by the convergence of water vapor appears to the south and the north of the positive center and over the Philippine Sea. During the CP La Niña winter, the center of the negative precipitation is also located over the central tropical Pacific but shifted slightly westward compared to that during the EP La Niña winter (Fig. 4b). The intensity of precipitation response to the CP La Niña is obviously stronger than that to the EP La Niña, which is associated with the stronger SST anomaly for the CP La Niña. Another possible reason is related to the different location of SST anomaly. Compared to the EP, the convection over the $\mathrm{CP}$ is much more sensitive to the SST anomaly because of a higher background SST (e.g., Kug et al. 2009). As such, the SST anomaly for the CP La Niña can induce stronger atmospheric response than that for the 
Fig. 3 Composites of SST anomalies (shading and contours in ${ }^{\circ} \mathrm{C}$ ) and surface wind anomalies (vectors in $\mathrm{m} / \mathrm{s}$ ) during DJF for a EP La Niña, and b CP La Niña. The SST anomalies that are not significant at the $95 \%$ level are not shown. Contour interval is $0.5^{\circ} \mathrm{C}$ and zero contours are omitted. Only values above $0.6 \mathrm{~m} / \mathrm{s}$ are shown for surface wind anomalies (a)

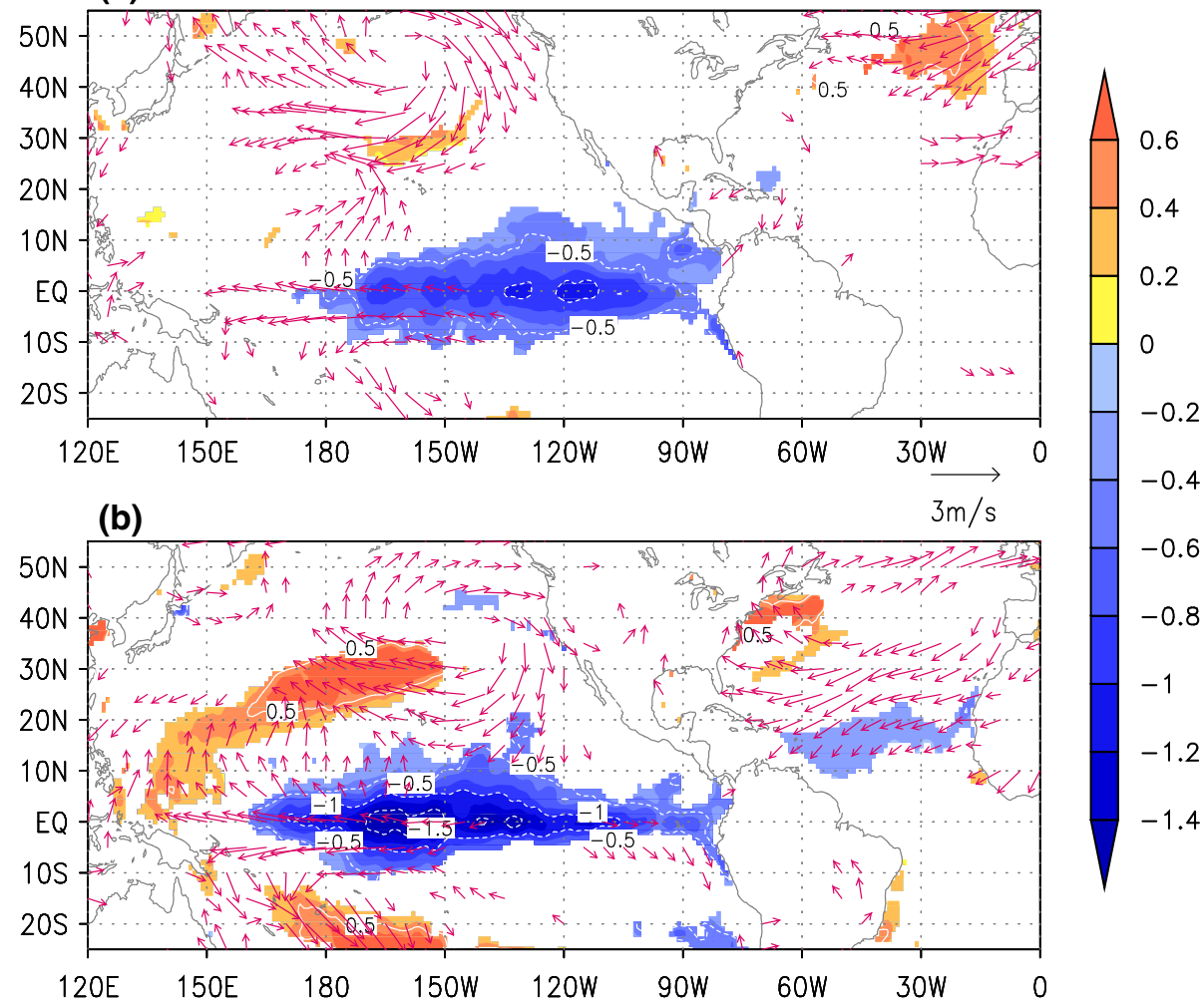

EP La Niña. Another difference in the moist convergence anomaly is that a more precipitation belt elongates northeastward from the Philippine Sea to the CP during the $\mathrm{CP}$ La Niña episode. The CMAP precipitation is also examined to investigate the convection anomalies for these two types of La Niña compositions after 1979 and their difference is similar to that indicated by the divergence of water vapor except for the region of the northwestern tropical Pacific (Fig. 4).

\section{Atmospheric responses over NA and WE}

The contrast in the tropical atmosphere anomalies, in association with different SST anomaly patterns of the two types of La Niña, may result in large differences in the extratropical circulation and thus regional climate. In this paper, we focus on the climate response over the NA-WE sector, in particular on their potential impacts on the NAO associated with these two types of La Niña since it is the dominant climate variability mode over the NA-WE sector. In general, ENSO events reach their peaks during late autumn and winter, however, the associated climate impacts over the NA and WE region are found to be significant during late winter (Gouirand and Moron 2003; Knippertz et al. 2003; Brönnimann et al. 2007b). To illustrate the seasonality of the ENSO signal, the NAO index is defined as the difference in the normalized monthly sea level pressure (SLP) regionally zonal-averaged over the NA-WE sector from $80^{\circ} \mathrm{W}$ to $30^{\circ} \mathrm{E}$ between $35^{\circ} \mathrm{N}$ and $65^{\circ} \mathrm{N}$ ( $\mathrm{Li}$ and Wang 2003). This simple NAO index is demonstrated to well describe the spatial-temporal characteristics associated with NAO (Li and Wang 2003). For the EP La Niña, the NAO index appears to be at a normal state in $\mathrm{ND}(0)$ (Fig. 5). During the JFM(1) period, a negative value corresponds to a negative NAO-like pattern indicative of a high pressure anomaly in the mid-latitude and a low pressure anomaly in the subtropics. This configuration is reversed from AM(1). For the CP La Niña, the atmospheric response in $\mathrm{N}(0)$ is characterized by a weak negative NAO-like pattern. The revised sign of the NAO index in following 3 months is manifested by a positive NAO-like pattern, demonstrating a low pressure anomaly to the north and a high pressure anomaly to the south (Fig. 5). As shown in Fig. 5, an opposite sign of the atmospheric response is observed in winter for the two types of La Niña, and the difference is most evident in $\mathrm{JF}(1)$. To detect the robust signal, we shall hereafter define "winter" as the JF period when investigating the atmospheric responses over the NAWE sector to the two types of La Niña. The "winter" can also be defined by $\mathrm{D}(0) \mathrm{JF}(1)$, and even $\mathrm{D}(0) \mathrm{JFM}(1)$ or $\operatorname{JFM}(1)$, and the qualitative conclusion is unchanged.

One prominent teleconnection associated with ENSO events has been referred to as the PNA pattern 
Fig. 4 Composites of vertically integrated moisture divergence (shading and black contours in $\mathrm{mm}$ /day) and CMAP precipitation (pink contours in $\mathrm{mm}$ /day) during DJF for a EP La Niña, and b CP La Niña. Shading presents values exceeding the 90 and $95 \%$ confidence level. Black and pink contour intervals are 1 and $2 \mathrm{~mm} /$ day, respectively. Zero contours are omitted (a)

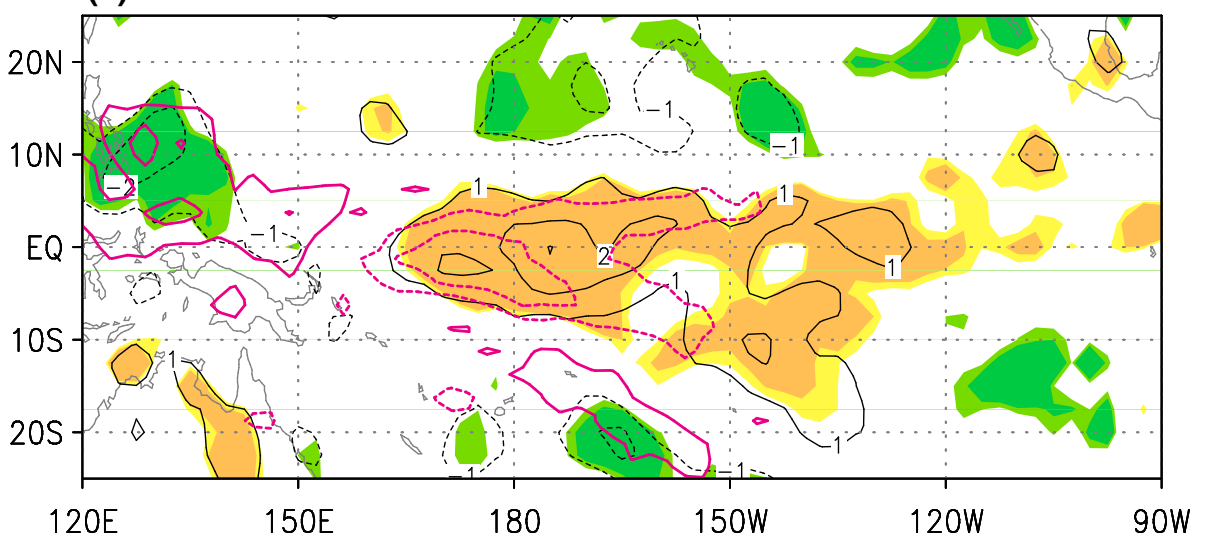

(b)

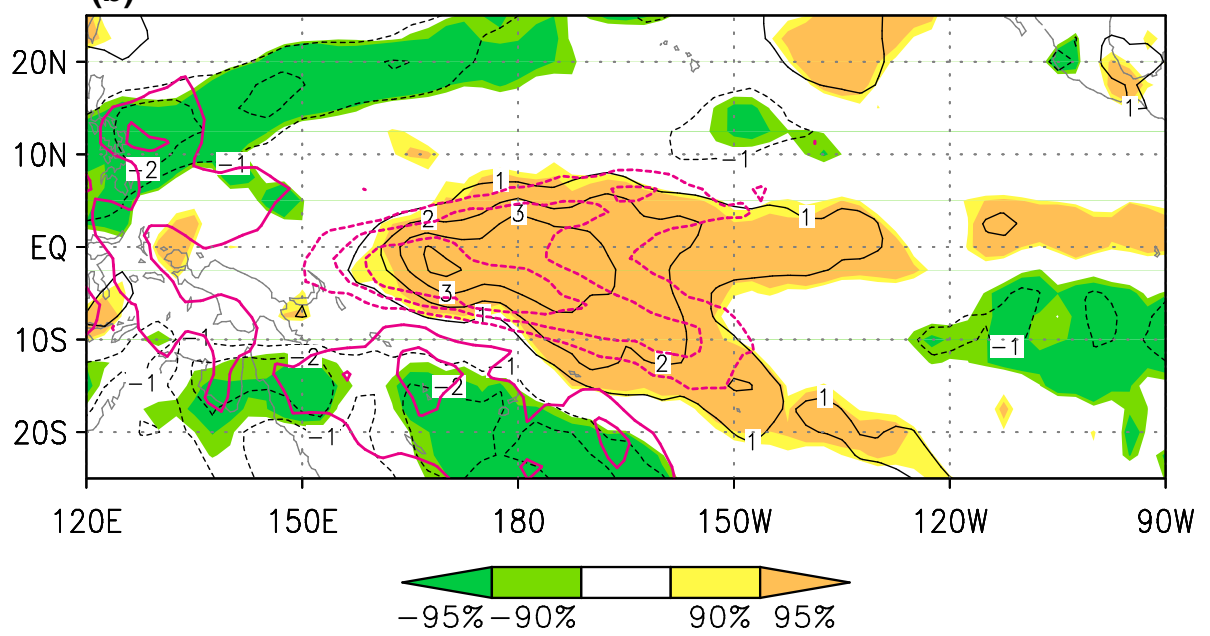

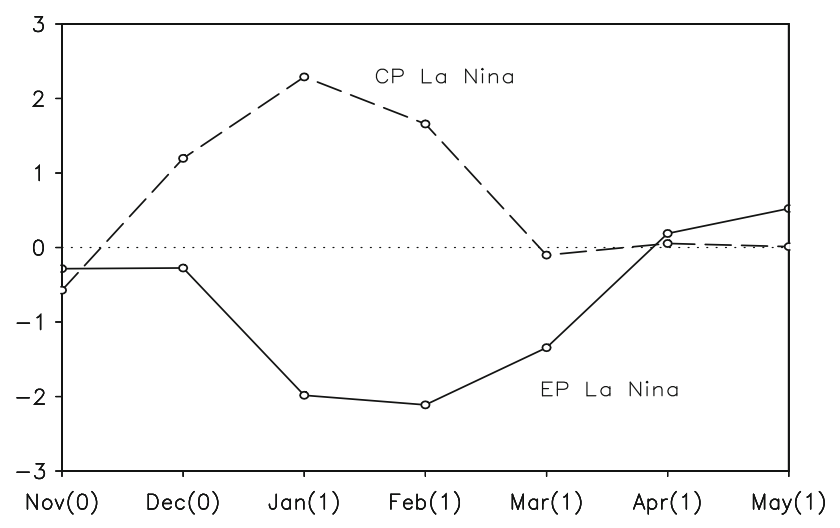

Fig. 5 Composite monthly evolution of the NAO index for EP La Niña (solid line) and CP La Niña (dashed line). The abscissa indicates a 7-month period from November of year 0 to May of year 1

accompanied by an intensified Aleutian low during ENSO warm phase. Corresponding to the ENSO cold phase, a positive SLP anomaly covers the North Pacific indicating a weakened Aleutian Low during both types of La Niña events (Fig. 6a, b). Compared to the EP La Niña composite, the significantly positive SLP anomaly is slightly shifted southeastward for the CP La Niña composite. However, their differences in SLP are pronounced over the NA-WE sector. During winter for the EP La Niña, a significantly high pressure anomaly to the north and a significantly low pressure anomaly to the south elongate zonally from the central North Atlantic to Europe (Fig. 6a). This SLP anomaly response resembles the negative NAO-like pattern. Nevertheless, the signal of the $\mathrm{CP} \mathrm{La}$ Niña is roughly opposite to that of the EP La Niña. A significant low (high) pressure anomaly to the north (south) extends zonally from the western to eastern NA (Fig. 6b), which corresponds to a positive NAO-like pattern.

As indicated by the composite geopotential height at $300 \mathrm{hPa}$ (Fig. 6c, d), the similar anomaly pattern in the lower troposphere can also be detected in the upper troposphere over the North Pacific and NA-WE regions. The barotropic features are shown in the atmospheric response to the two types of La Niña over the mid-latitude regions. The result is consistent with the previous study (Ting 1996), in which it is pointed out that the tropical heating 

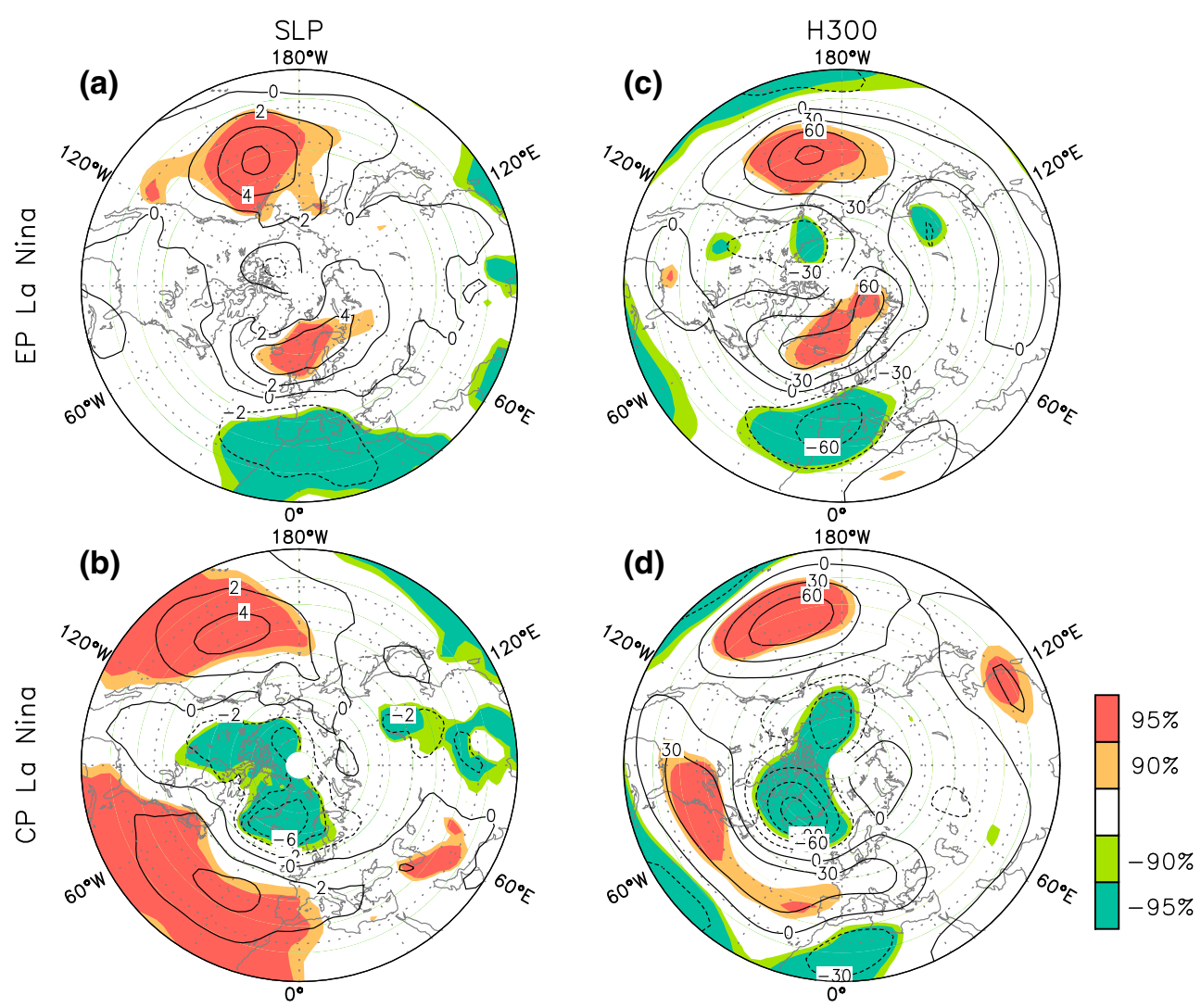

Fig. 6 Composites of JF SLP anomalies (hPa) for a EP La Niña and b CP La Niña, and JF geopotential height anomalies (m) at $300 \mathrm{hPa}$ for c EP La Niña and d CP La Niña. Shading indicates values

exceeding the 90 and $95 \%$ confidence level. Contour intervals in (a, b) and (c, d) are $2 \mathrm{hPa}$ and $30 \mathrm{~m}$, respectively

can cause a barotropic response in the atmospheric circulation over the extratropics.

It is suggested that the subtropical jet is of importance in bridging the ENSO and NAO teleconnection (Graf and Zanchettin 2012). Here, the composite zonal wind anomalies at $200 \mathrm{hPa}$ are displayed to investigate the change in jet stream for the two types of La Niña (Fig. 7). In association with the EP La Niña, the zonal wind anomalies at $200 \mathrm{hPa}$ over the North Pacific exhibit a tripolar structure and tilt slightly southeastward (Fig. 7a). In the mid-latitude of the North Pacific, significantly negative anomalies suggest a weakening East Asia subtropical jet. These anomalies elongate zonally from the western Pacific and stay west of $60^{\circ} \mathrm{W}$. Almost opposite anomaly structure in $200 \mathrm{hPa}$ zonal wind emerges over the NA. The Atlantic jet is significantly weakened indicated by a negative anomaly in zonal wind at $200 \mathrm{hPa}$ (Fig. 7a), corresponding to a negative NAO-like atmospheric response (Fig. 6a, c). During the CP La Niña, a similarly tripolar structure in $200 \mathrm{hPa}$ zonal wind anomalies appears over the North Pacific, however, the location is displaced equatorward. The anomalies elongate zonally from the North Pacific and extend far eastward to the NA. The Atlantic jet is

significantly strengthened and extends farther eastward reaching WE, which corresponds to the positive NAO-like atmospheric anomalies as shown in Fig. 6b, d. It can be seen that the two types of La Niña could lead to a roughly opposing response in the Atlantic jet, consistent with an opposing NAO-like pattern over the NA (Figs. 5, 6).

Many studies have demonstrated that the NAO contributes significantly to surface temperature and precipitation over the WE during winter (see the review of Jones et al. 2003). The approximately opposing atmospheric responses to the two types of La Niña over the NA may result in diametric climate anomalies over WE. As expected, the anomalies in surface air temperature and precipitation show very different patterns (Fig. 8). During the EP La Niña winter, the weakened Atlantic jet associated with the negative NAO phase tends to transport unusually cold and dry air to WE. Thus a winter occurs over WE that is colder than normal, where the anomalous surface air temperature can reach $-2{ }^{\circ} \mathrm{C}$ (Fig. 8). Simultaneously, the precipitation is reduced in most regions of WE, whereas the southwestern region including Spain and Portugal receives excessive precipitation, which is likely associated with the strengthened zonal wind to the south of 
Fig. 7 Composites of JF zonal wind anomalies $(\mathrm{m} / \mathrm{s})$ at $200 \mathrm{hPa}$ for a EP La Niña and b CP La Niña. Shading indicates values exceeding the 90 and $95 \%$ confidence level. Contour intervals are $2 \mathrm{~m} / \mathrm{s}$ (a)

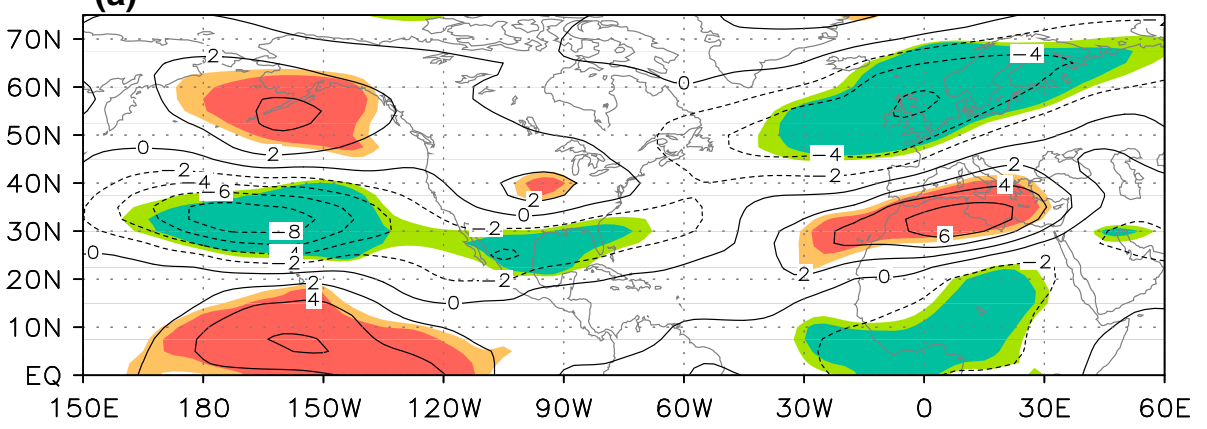

(b)

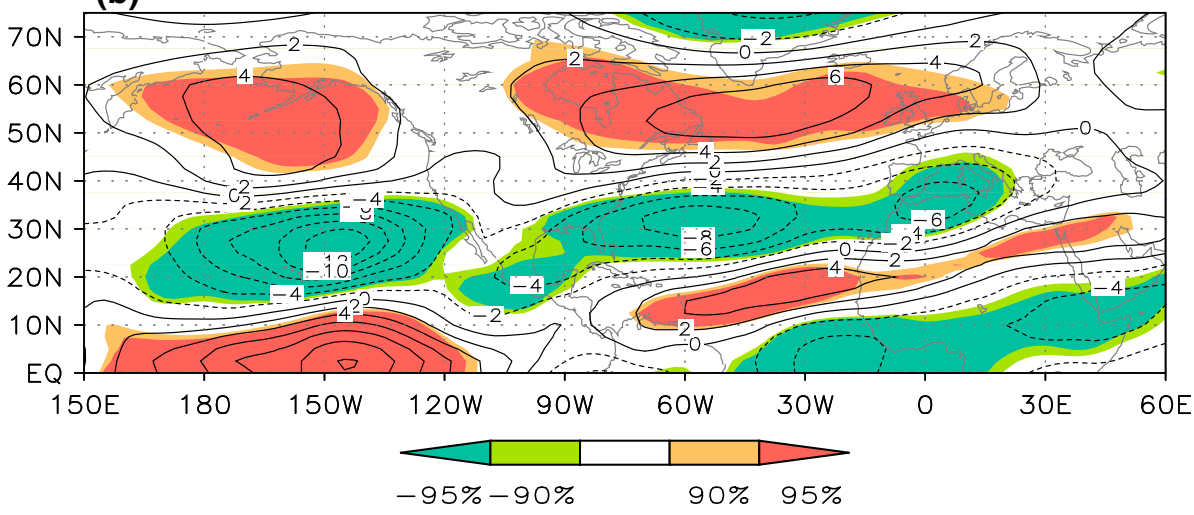

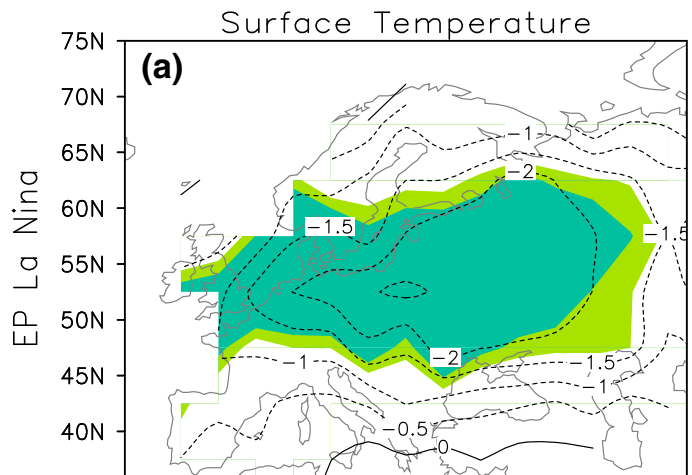

Precipitation
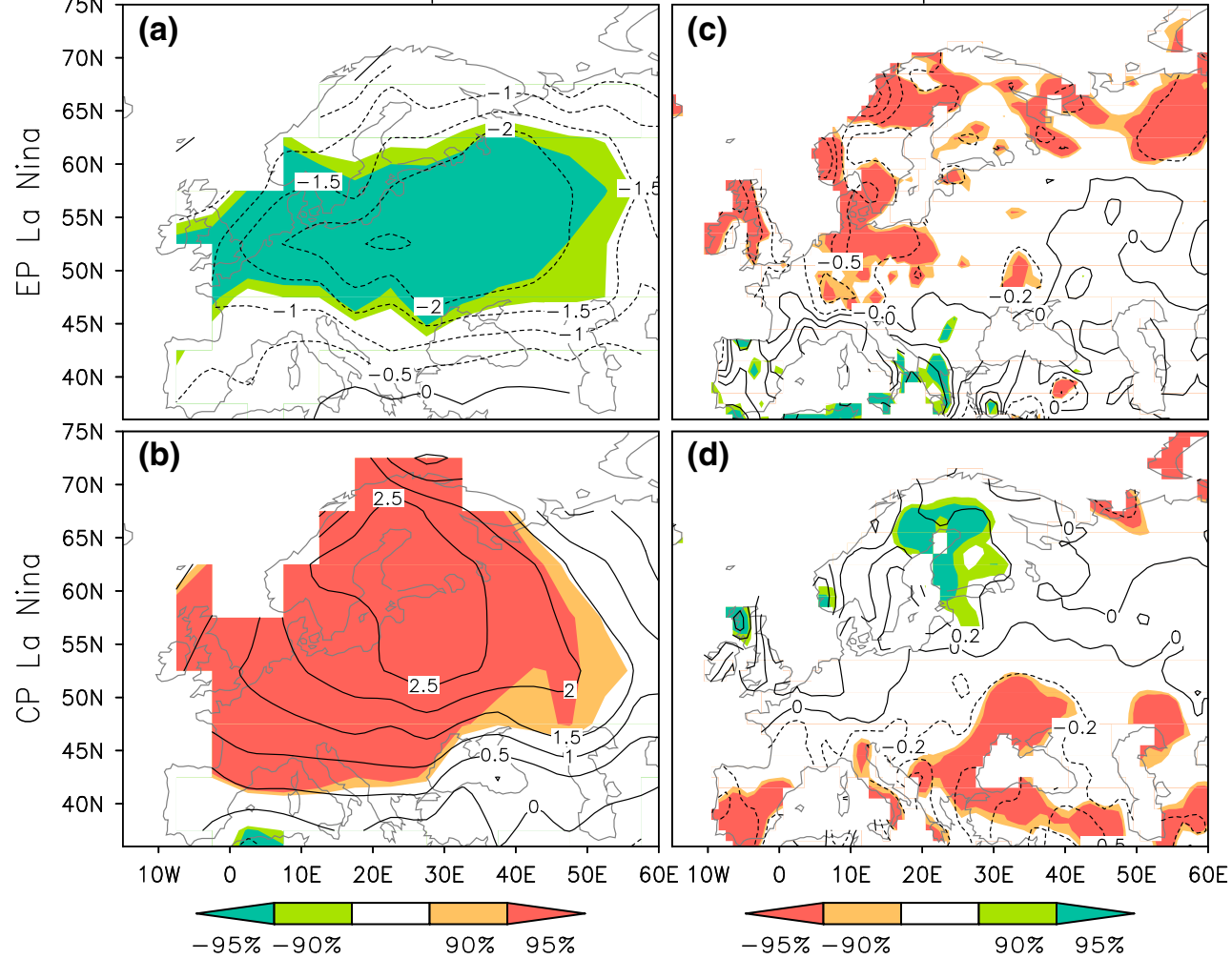

Fig. 8 Composites of JF surface air temperature anomalies (contours in ${ }^{\circ} \mathrm{C}$ ) for a EP La Niña and $\mathbf{b}$ CP La Niña, and JF GPCC precipitation anomalies (contours in mm/day) for $\mathbf{c}$ EP La Niña and d CP La Niña.

Shading indicates values exceeding the 90 and $95 \%$ confidence level. Contour intervals in $(\mathbf{a}, \mathbf{b})$ and $(\mathbf{c}, \mathbf{d})$ are $0.5{ }^{\circ} \mathrm{C}$ and $0.2 \mathrm{~mm} /$ day, respectively 

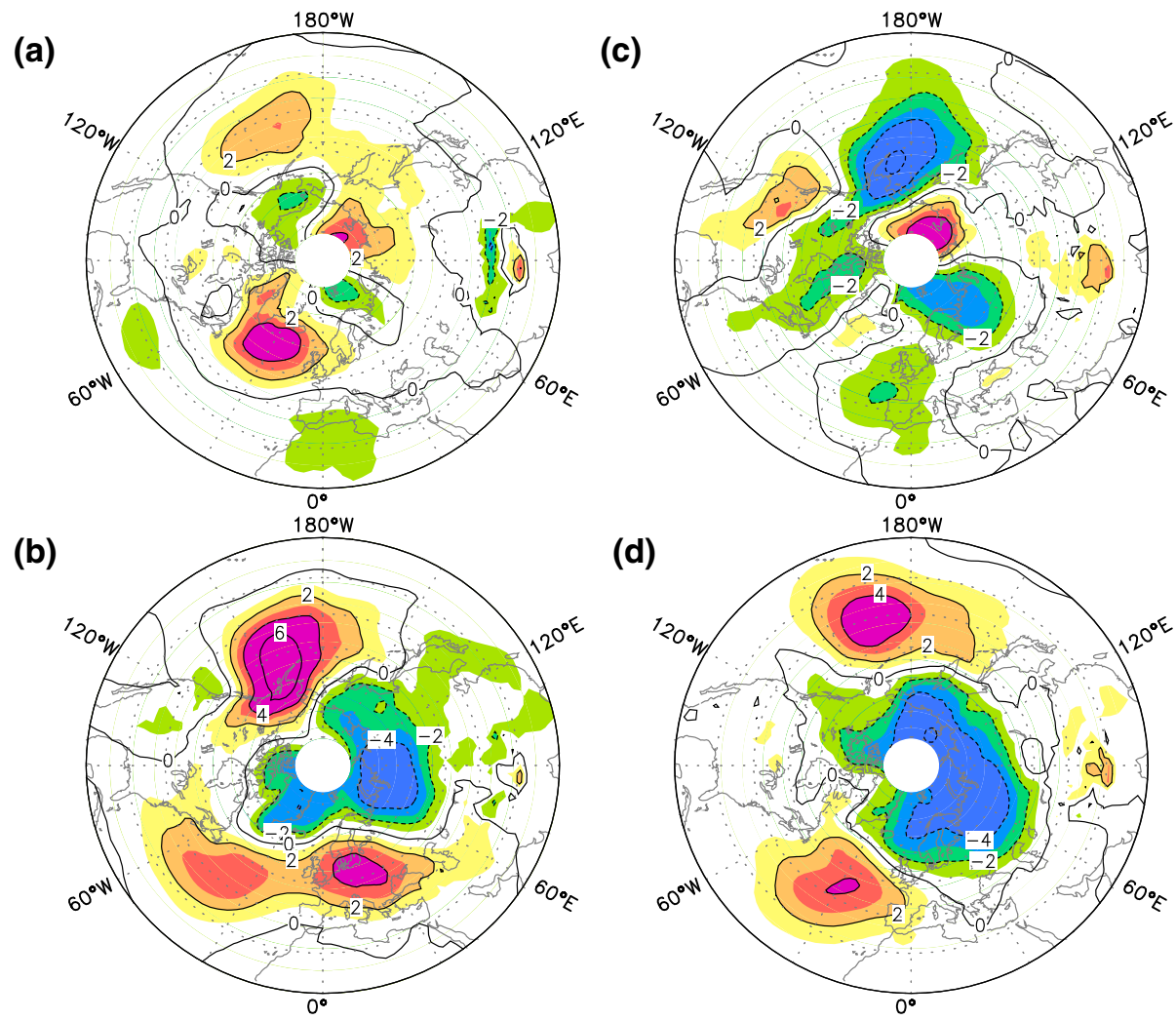

(d)

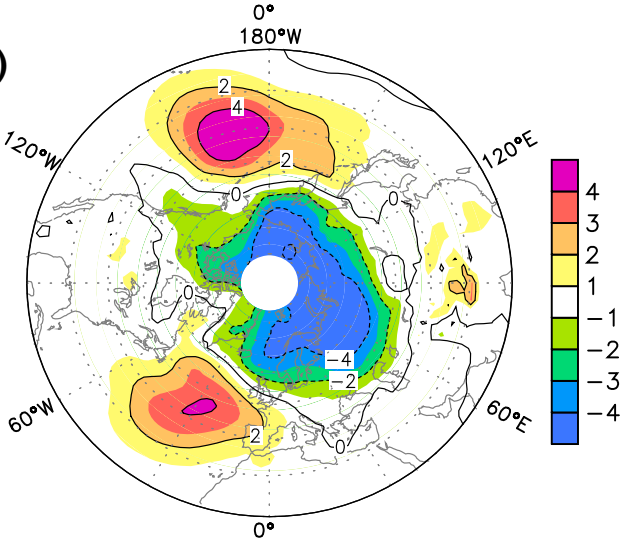

Fig. 9 The ensemble mean JF SLP response (hPa) to a EP_COOL, b CP_COOL, c CP_WARM, and d CP_CW forcings. Contour intervals are $2 \mathrm{hPa}$

the Atlantic jet (Fig. 7a). In comparison, WE experiences a warmer than normal winter during the CP La Niña winter. This is because that the enhanced Atlantic jet across the NA related to the positive NAO phase tends to transport relatively warm and moist air to WE. The precipitation anomalies are characterized by a dipolar structure with increasing (decreasing) over northern (southern) WE. As demonstrated in Fig. 8, WE experiences a very different climate anomalies corresponding to the two different types of La Niña. Therefore, it is necessary to consider the two types of La Niña events when understanding their climate impacts.

\section{Mechanisms for the contrasting impacts over NA-WE of two types of La Niña}

According to the observed analyses above, different SST anomaly patterns during the two types of La Niña are possibly responsible for the approximately opposing NAOlike atmospheric anomalies. To verify it, four experiments were designed and performed, which has been described in Sect. 2. Figure 9 shows the SLP responses to the EP_COOL, CP_COOL, CP_WARM, and CP_CW forcings relative to the CNTRL run. In the EP_COOL simulations, the imposed tropical SST cooling induces a weakened Aleutian Low and a negative NAO-like atmospheric anomaly indicated by a high SLP anomaly to the north and a low SLP anomaly to the south of the North Atlantic (Fig. 9a). These anomalies closely resemble the observed EP La Niña composition (Fig. 6a). Under the CP_COOL forcing, a positive SLP anomaly appears over the North Pacific and a positive NAO-like atmospheric response occurs over the North Atlantic (Fig. 9b). These features agree well with the observed anomaly patterns during the CP La Niña winter (Fig. 6b). Similarly anomalous patterns are also simulated in the upper troposphere over the North Pacific and North Atlantic (Fig. 10a, b). Consistent with the observations, different cooling SST anomaly patterns for the two types of La Niña can cause similar responses of the Aleutian Low, but they trigger roughly opposing NAOlike atmospheric responses.

Previous studies (e.g., Li et al. 2006) have discussed importance of the western Pacific warming. Here, the CP_WARM experiment is conducted to inspect possible impacts of the western Pacific warming on the North Atlantic atmosphere. As shown in Figs. 9c and 10c, circumglobal wave train is displayed, suggesting that the CP_WARM has a minor impact on the positive NAO-like atmospheric response for the CP La Niña. We also consider 
Fig. 10 The ensemble mean JF geopotential height response (m) at $300 \mathrm{hPa}(\mathrm{hPa})$ to a EP_COOL, b CP_COOL, c CP_WARM, and d CP_CW forcings. Contour intervals are $20 \mathrm{~m}$

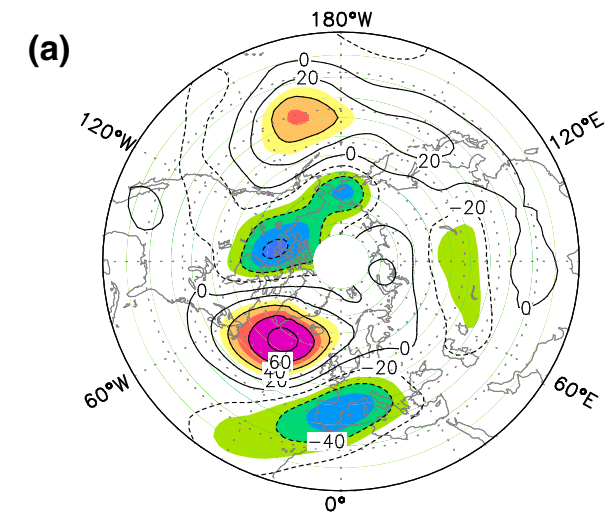

(c)

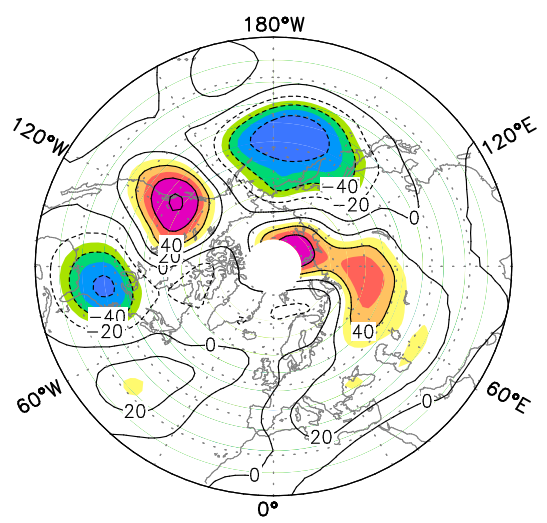

(b)

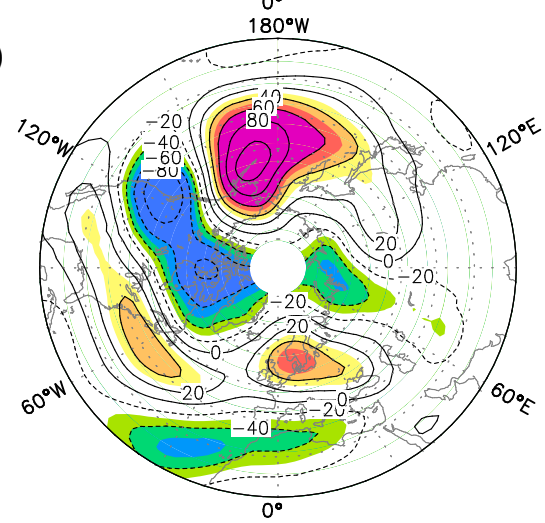

the impacts of both cooling and warming SST anomalies over the tropical Pacific in the CP_CW simulation. Their responses appear to be a mixture of the $\mathrm{CP} \_\mathrm{COOL}$ and CP_WARM responses (Figs. 9d, 10d), which are largely the same as those of the CP_COOL forcing.

In addition, many studies reported that the tropical Pacific heating have effects on the tropical Atlantic SST anomaly (Wolter 1987; Curtis and Hastenrath 1995; Gallego et al. 2001; Alexander et al. 2002; Huang et al. 2002), which is argued to affect the North Atlantic atmosphere (e.g., Watanabe and Kimoto 1999; Robertson et al. 2000). Therefore, the tropical Atlantic SST may serve as a mediator to link the tropical Pacific SST anomaly and the NA atmosphere. In order to examine the possible effects of the tropical Atlantic SST, Fig. 3 also presents the SST and surface wind anomalies over the Atlantic during the two types of La Niña winters. For the EP La Niña, almost no significant SST anomalies are observed over the tropical Atlantic but the SST warming over the eastern NA is robust (Fig. 3a). The warm SST anomaly is arguably due to the cyclonic circulation and the associated easterly wind anomalies, which could weaken the strong background westerlies and thus the local evaporation. In contrast to the EP La Niña, there appear significantly cold SST anomalies over the northern tropical Atlantic and warming SST anomalies over the western NA during the CP La Niña winters (Fig. 3b). In accordance with the SST anomaly pattern, an unusually anticyclonic circulation occurs over the NA. Over the western mid-latitude Atlantic, the anomalous southeasterlies can possibly pile up the surface warm water and lead to increase in the SST there (Fig. 3b). The SST cooling in the tropical Atlantic could also be regarded to be a consequence due to the strengthened easterlies and thus evaporation through wind-evaporationSST feedback.

Here, another series of experiments (AT_COOL) are performed to inspect the possible effect of the cooling SST anomaly over the northern tropical Atlantic during the $\mathrm{CP}$ La Niña winter. Figure $11 \mathrm{a}$, c show the atmospheric responses at the lower and upper troposphere in the AT_COOL simulations relative to the control run. The AT_COOL forcing can trigger positive NAO-like atmospheric anomalies, suggesting that the cooling SST anomaly at the northern tropical Atlantic Ocean has contribution to the NA atmospheric anomaly during the CP La Niña event. However, the Aleutian Low is strengthened under the forcing of the AT SST anomaly, implying the dominant forcing effect from the tropical Pacific rather than the local SST. Furthermore, we conducted another experiment (CPAT_COOL), in which the CP_COOL and AT_COOL forcings are imposed together. As shown in Fig. $11 \mathrm{~b}, \mathrm{~d}$, the Aleutian Low is weakened and positive NAO-like atmospheric anomalies occur under the CPAT_COOL forcing. The atmospheric responses 

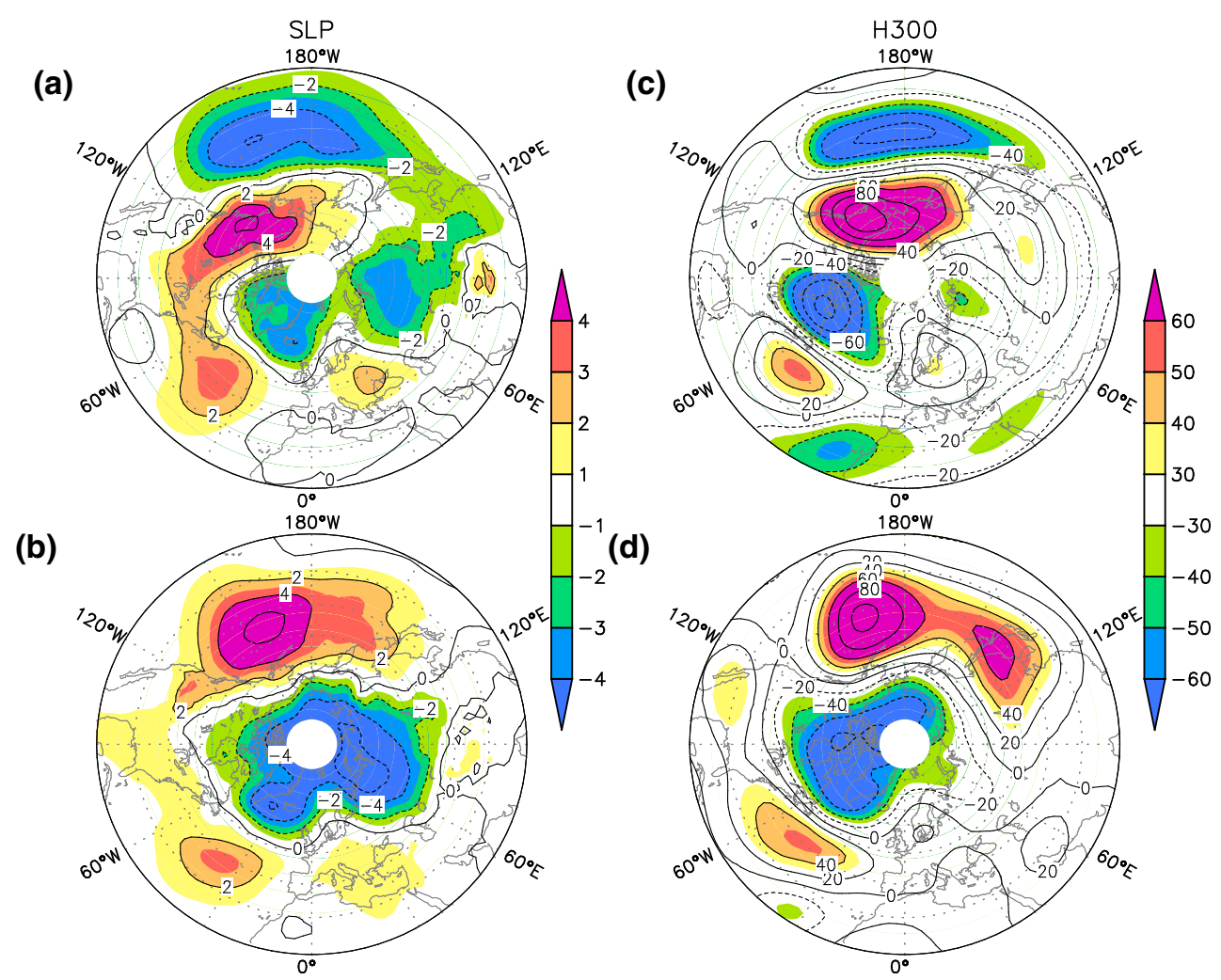

Fig. 11 The ensemble mean JF SLP response to a AT_COOL and b CPAT_COOL forcings. Contour intervals are $2 \mathrm{hPa}$. The ensemble mean JF geopotential height response $(\mathrm{m})$ at $300 \mathrm{hPa}(\mathrm{hPa})$ to c AT_COOL and d CPAT_COOL forcings. Contour intervals are $20 \mathrm{~m}$

resemble closely those of the $\mathrm{CP}_{-} \mathrm{COOL}$ and $\mathrm{CP} \_\mathrm{CW}$ forcings, but with a slight improvement in the NA-WE region compared to the observed pattern (Figs. 6b, d, 9b, d, $10 \mathrm{~b}, \mathrm{~d}, 11 \mathrm{~b}, \mathrm{~d})$. It can be seen that the AT_COOL forcing has some contribution on the local atmospheric anomalies.

A series of modelling experiments discussed above suggest that the two types of La Niña have different impacts on the NA-WE atmosphere through the atmospheric teleconnection. The tropical Atlantic SST anomalies associated with the CP La Niña also have effects on NA atmospheric anomalies. Although the simulated experiments suggest that the contrasting atmospheric anomalies in the NA are mainly attributed to different cooling SST anomaly patterns for the two types of La Niña, dynamical mechanism addressing how the tropical SST influences the NA-WE atmosphere is still an open question. The atmosphere over the North Pacific is usually argued to be linked to the tropical Pacific heating and the NA-WE atmosphere anomalies (e.g., Wu and Hsieh 2004; $\mathrm{Li}$ and Lau 2012). The North Pacific anomalies could modify local mean flow and standing waves, which possibly propagate downstream to the North Atlantic and leads to different NAO-like atmospheric responses. There exhibits a nonlinear relationship between the atmospheric anomalies over the North Pacific and NA. For example,
Castanheira and Graf (2003) demonstrated that a significantly negative correlation could be detected between the SLP over the North Pacific and the NA only when the polar vortex is strong enough. Recently, the subtropical jet is also emphasized to act as an "atmospheric bridge" to connect the tropical Pacific heating and NA-WE atmospheric anomalies (Graf and Zanchettin 2012). Further studies are required to understand the mechanisms behind the contrasting atmospheric anomalies over the Atlantic Ocean with these two types of La Niña.

\section{Discussion: Asymmetry in influences of ENSO on climate over the NA-WE sector}

An investigation discussed above shows that the two types of La Niña have roughly opposing impacts on the atmosphere over the NA-WE sector. A significantly negative (positive) NAO-like pattern is observed during the EP (CP) La Niña winters. The previous study (Graf and Zanchettin 2012) have compared the climate impacts associated with the EP and CP El Niño events and suggested that the two types of El Niño lead to distinctly different atmospheric responses over the NA-WE region. It is found that a significantly negative NAO-like pattern occurs over the 
Fig. 12 a Scatter plot of the DJF Nino3 index and JF (January-February) NAO index for EP El Niño (red triangle) and EP La Niña (blue triangle). Red and blue solid circles are the composites of EP El Niño and EP La Niña, respectively. b Same as (a), but for CP El Niño and CP La Niña
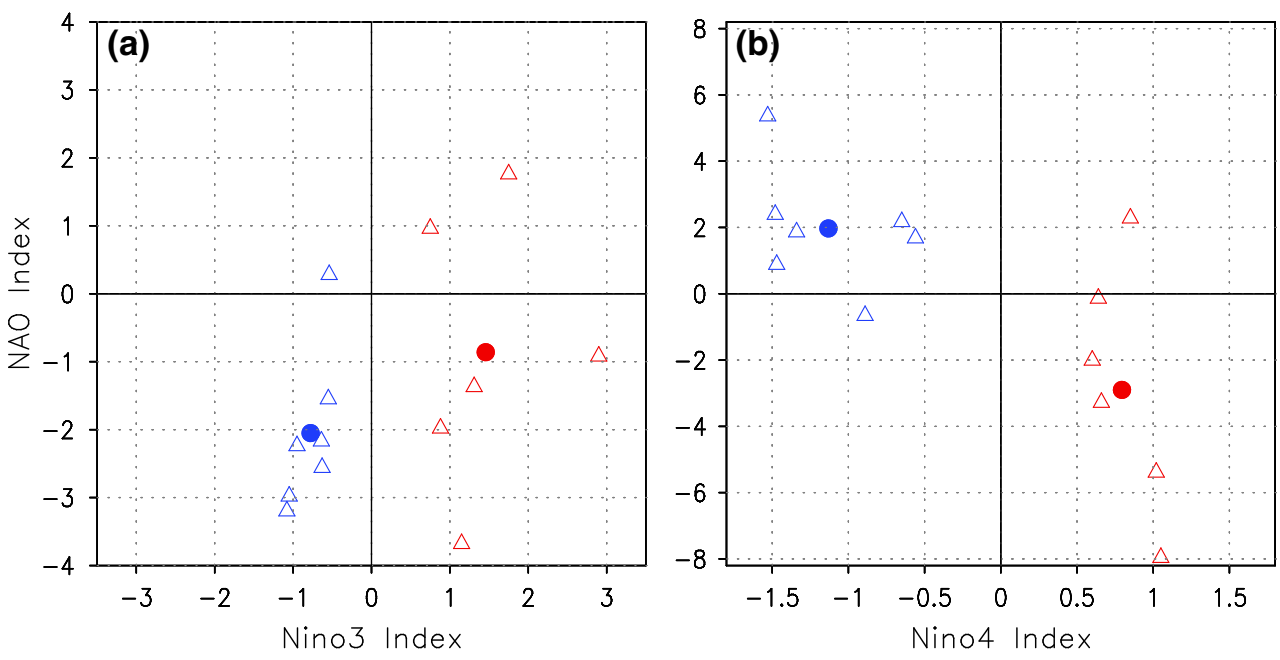

Fig. 13 DJF SST anomaly (contours in ${ }^{\circ} \mathrm{C}$ ) regressed upon JF NAO index from 1950/1951 to 2009/2010. Light (dark) shading indicates regression exceeding the $90 \%$ (95\%) confidence level. Contour intervals are $0.1{ }^{\circ} \mathrm{C}$

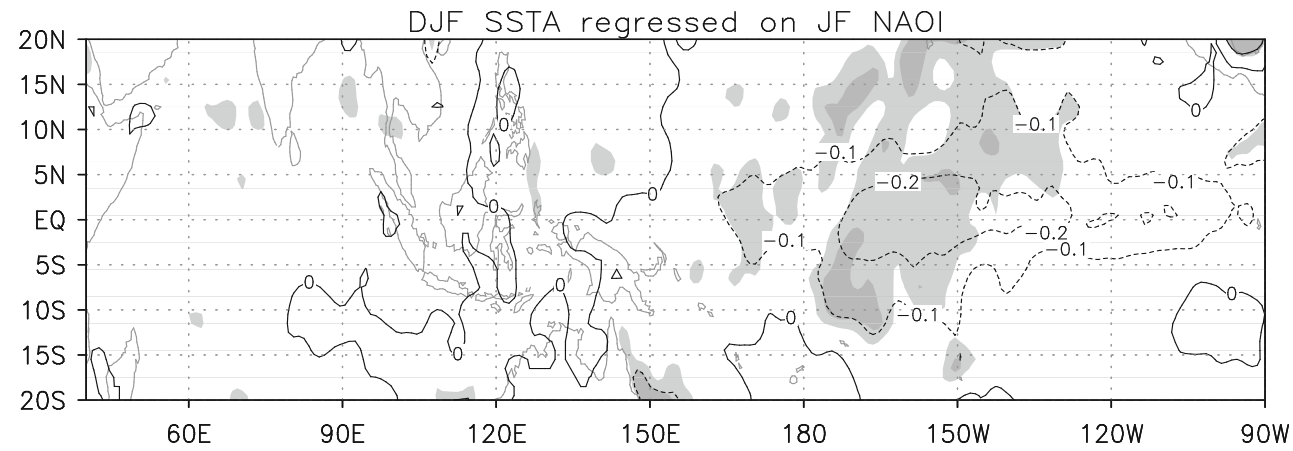

NA-WE region during the $\mathrm{CP}$ El Niño winter, whereas no apparent signal is found there during the EP El Niño winter.

To clearly inspect the symmetry between the warm and cold phases of ENSO, Fig. 12a, b display the relationship between NAO and the two types of ENSO, respectively. Following the study of Graf and Zanchettin (2012), EP El Niño events identified are 1951, 1957, 1965, 1972, 1976, and 1997; and CP El Niño events selected are 1968, 1977, 1986, 1994, 2002, and 2009. Some El Niño events are excluded in their definition because concurrent volcanic eruptions also have an important impact on the mid-latitude climate (Graf and Zanchettin 2012). The SST anomaly over the Niño3 region is used to denote the EP ENSO events since the dominant SST anomaly is confined to the eastern equatorial Pacific. Similarly, we referred to the Niño4 index as the CP ENSO events considering their SST anomaly occurring mainly over the central equatorial Pacific.

As shown in Fig. 12a, a negative NAO index appears in most of the EP La Niña winters. Their composite NAO index reaches -2.1 , which is statistically significant at the $95 \%$ confidence level. However, four out of six EP El Niño events are in favor of occurrence of a negative NAO- like pattern, and another two events correspond to a positive NAO-like pattern (Fig. 12a). Their composite result shows a weak negative NAO index, which is not significant at the $95 \%$ confidence level. It is consistent with the previous study (Graf and Zanchettin 2012) suggesting that the atmospheric response to the EP El Niño over the NAWE region seems to be originated by chance. As a consequence, the EP El Niño effect on NAO seems to be asymmetric to the EP La Niña effect during winter.

Unlike the EP ENSO events, the CP ENSO events exhibit linearity in their climate impacts over the NA-WE sector (Fig. 12b). Six out of seven CP La Niña events tend to result into a positive NAO-like atmospheric anomaly, whereas five out of six CP El Niño events are in favor of occurrence of a negative NAO index. Their compositions are both significant at the $95 \%$ confidence level, indicating that the NA-WE atmospheric anomalies during the $\mathrm{CP}$ ENSO winters are most likely not due to chance. It can be seen that the NA-WE atmospheric response to the CP SST anomaly is very different from that to the EP SST anomaly. Figure 13 displays the relationship between the NAO index and tropical SST anomaly indicated by the linear correlation. As shown in Fig. 13, the NAO index is significantly correlated with the CP SST anomaly near $150^{\circ}-180^{\circ} \mathrm{W}$. It 
Fig. 14 Composites of SST anomalies (shading and contours in ${ }^{\circ} \mathrm{C}$ ) during autumn (SON) for a EP La Niña, and b CP La Niña. The SST anomalies that are not significant at the $95 \%$ level are not shown. Contour intervals are $0.5{ }^{\circ} \mathrm{C}$ and zero contours are omitted (a)

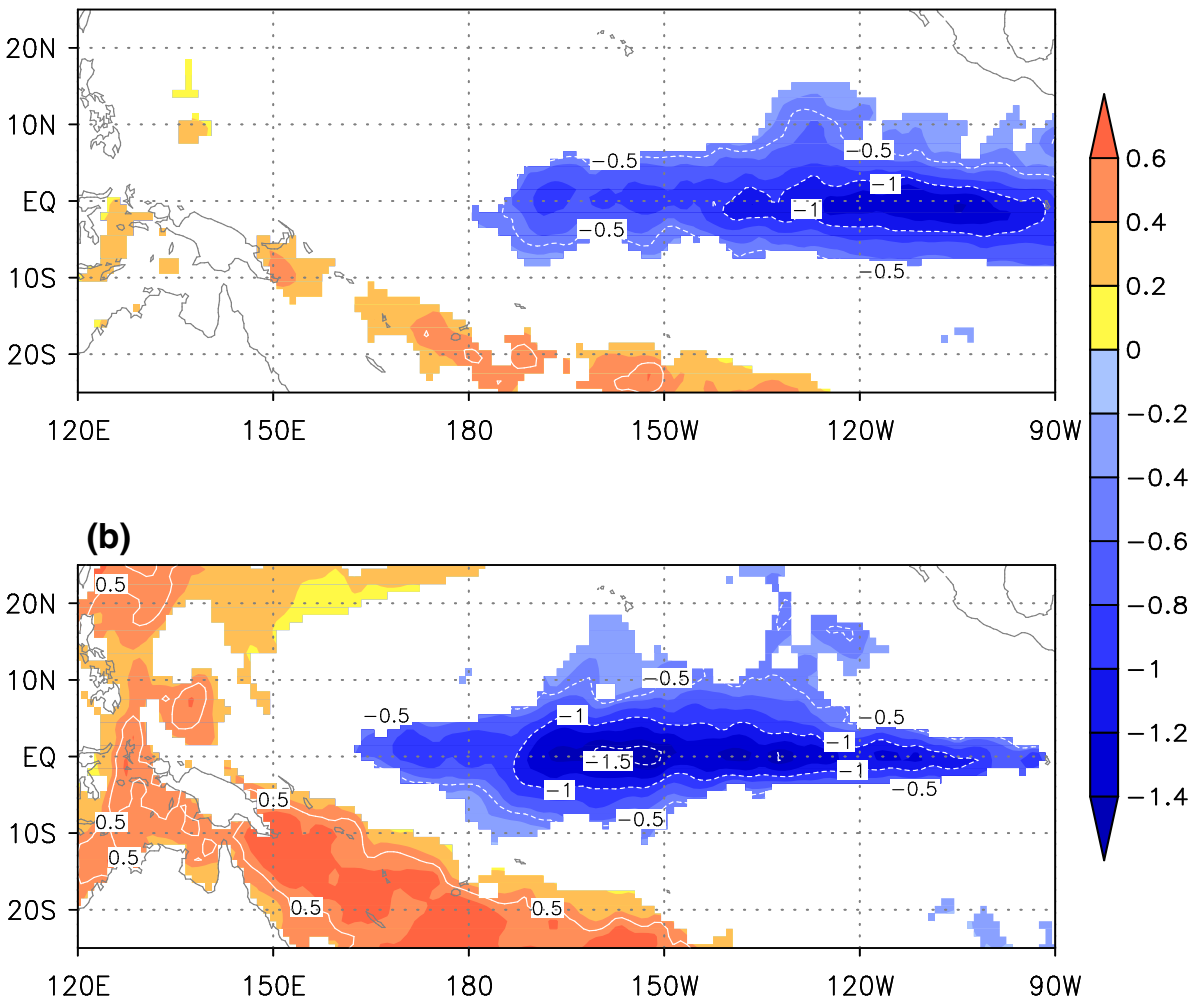

suggests that a positive SST anomaly over the CP is usually accompanied by a negative NAO-like atmospheric anomaly, and vice versa. However, there is no significant correlation between the NAO index and the EP SST anomaly. Only the linear part of the relationship can be examined in correlation analysis. The signal of the EP La Niña over the NA-WE region is easily overlooked using a correlation analysis. It is a possible reason that the traditional (or EP) ENSO signal is difficult to be detected in the North Atlantic and its adjacent land. Other methods such as composition need to be used to detect the nonlinear relationship. However, the physical mechanisms are not clear for the asymmetry and deserve study in future.

\section{Conclusions}

Similar to the El Niño phenomena discussed previously, this study has shown that the La Niña should be classified into two types (i.e., the EP and CP La Niña) considering their distinctly different climate impacts. The EP La Niña is characterized by the cooling SST anomaly center confined to the EP east of $150^{\circ} \mathrm{W}$ and relatively weak SST anomaly observed over the CP. By contrast, the SST anomaly center associated with the CP La Niña is shifted westward into the $\mathrm{CP}$ west of $150^{\circ} \mathrm{W}$ and small cooling SST anomaly is found over the EP. The two types of La
Niña exhibit very different features in the SST anomaly evolution. For the EP La Niña, the SST anomaly starts in the EP and propagates westward during the developing and mature phase, while the CP La Niña shows a standing feature with its SST anomaly developing and decaying in situ over the CP. These differences in zonal location of SST anomaly and their evolutions suggest the possibility in different underlying dynamics.

Although the two types of La Niña can produce a similar response in the atmosphere over the north Pacific, distinctly different teleconnection patterns are found over the NAWE sector. For the EP La Niña, the NA-WE region experiences the climate anomalies resembling a negative NAO pattern accompanied by a weakening Atlantic jet. This weakening jet tends to inhibit a strong transportation of warm and moist air from the Atlantic sea and cause a cooler and drier than normal winter over the WE region. However, roughly opposing atmospheric anomalies appear over the NA-WE sector during the CP La Niña winter, which seems like a positive NAO phase with strengthening Atlantic jet. The strong jet tends to bring more warm and moist air from the sea to the WE area and results into a warmer and wetter than normal winter there. A series of modeling experiments indicate that the contrasting NAOlike patterns are mainly attributed to different cooling SST patterns for two types of La Niña. The analyses provided here have shown that it is necessary to separate the La Niña 
into two types considering their different SST anomaly location and evolution, and especially, very different climate impacts over the extratropics.

Although ENSO events usually reach their mature phase in winter, the associated strong SST anomaly pattern is clearly observed during the preceding autumn. As shown in Fig. 2, the La Niña events tend to intensively develop from August to December and decay in the following months, which has also been mentioned by previous studies (e.g., Larkin and Harrison 2001). Figure 14 displays the composite SST anomaly corresponding to the two types of La Niña during the developing autumn (September-November). The SST anomaly structure and intensity in the autumn is similar to those in the winter, indicating that the related SST anomaly signal in the mature phase can be obviously observed in the autumn. If the SST signal of La Niña is observed over the equatorial Pacific during the autumn, we easily expect that the La Niña event would persist into winter. It provides a potential predictability source for predicting the NA-WE climate anomalies at least a season in advance based on the strong cooling SST anomaly at the equator.

Acknowledgments This work is supported by the National Basic Research Program "973" (2012CB417403), the National Nature Science Foundation of China (41005049), the Special Fund for Public Welfare Industry (Meteorology) (GYHY201206016), and the Priority Academic Program Development of Jiangsu Higher Education Institutions (PAPD). BX is supported by APEC Climate Center. BX also acknowledges partial support from International Pacific Research Center which is sponsored by the JAMSTEC, NASA and NOAA.

Open Access This article is distributed under the terms of the Creative Commons Attribution License which permits any use, distribution, and reproduction in any medium, provided the original author(s) and the source are credited.

\section{References}

Afzaal M, Li JP, Jin FF (2013) The asymmetric influence of the two types of El Niño and La Niña on summer rainfall over Southeast China. J Clim 26:4567-4582

Neale RB et al (2010) Description of the NCAR Community Atmosphere Model (CAM 5.0), Tech Note NCAR/TN486+STR, Natl Cent for Atmos Res, Boulder, Colo June. http://www.cesm.ucar.edu/models/cesm1.0/cam/docs/description/ cam5_desc.pdf

Alexander MA, Bladé I, Newman M, Lanzante JR, Lau NC, Scott JD (2002) The atmospheric bridge: the influence of the ENSO teleconnections on air-sea interaction over the global oceans. J Clim 15:2205-2231

Ashok K, Behera S, Rao AS, Weng HY, Yamagata T (2007) El Niño Modoki and its possible teleconnection. J Geophys Res 112:C11007. doi:10.1029/2006JC003798

Branston A, Livezey RE (1987) Classification, seasonality, and persistence of low-frequency circulation patterns. Mon Weather Rev 115:1083-1126

Brönnimann S (2007) Impact of El Niño-Southern Oscillation on European climate. Rev Geophys 45:RG3003. doi:10.1029/ 2006RG000199
Brönnimann S, Ewen T, Griesser T, Jenne R (2007a) Multidecadal signal of solar variability in the upper troposphere during the 20th century. Space Sci Rev 125:305-315

Brönnimann S, Xoplaki E, Casty C, Pauling A, Luterbacher J (2007b) ENSO influence on Europe during the last centuries. Clim Dyn 28:181-197

Cai W, Cowan T (2009) La Niña Modoki impacts Australia autumn rainfall variability. Geophys Res Lett 36:L12805. doi:10.1029/ 2009GL037885

Castanheira JM, Graf HF (2003) North Pacific-North Atlantic relationships under stratospheric control? J Geophys Res 108:4036. doi:10.1029/2002JD002754

Curtis S, Hastenrath S (1995) Forcing of anomalous sea-surface temperature evolution in the tropical Atlantic during Pacific warm events. J Geophys Res 100C:15835-15847

Feng J, Li JP (2011) Influence of El Niño Modoki on spring rainfall over South China. J Geophys Res 116:D13102. doi:10.1029/ 2010JD015160

Feng J, Li JP (2013) Contrasting impacts of two types of ENSO on the boreal spring Hadley circulation. J Clim 26:4773-4789

Feng J, Wang L, Chen W, Fong SK, Leong KC (2010) Different impacts of two types of Pacific Ocean warming on Southeast Asia rainfall during boreal winter. J Geophys Res 115:D24122. doi:10.1029/2010JD014761

Gallego D, García R, Hernández E, Gimeno L, Ribera P (2001) An ENSO signal in the North Atlantic subtropical area. Geophys Res Lett 28:2939-2942

Garfinkel CI, Hartmann DL (2010) Influence of the quasi-biennial oscillation on the North Pacific and El Niño teleconnections. J Geophys Res 115:D20116. doi:10.1029/2010JD014181

Gill AE (1980) Some simple solutions for heat-induced tropical circulation. Q J R Meteorol Soc 106:447-462

Gouirand I, Moron V (2003) Variability of the impact of El Niño-Southern Oscillation on sea-level pressure anomalies over the North Atlantic in January to March (1874-1996). Int J Climatol 23:1549-1566

Graf HF, Zanchettin D (2012) Central Pacific El Niño, the "subtropical bridge", and Eurasian climate. J Geophys Res 117:D01102. doi:10.1029/2011JD016493

Greatbatch RJ, Lu J, Peterson KA (2004) Nonstationary impact of ENSO on Euro-Atlantic winter climate. Geophys Res Lett 31:L02208. doi:10.1029/2003GL018542

Halpert MS, Ropelewski CF (1992) Surface temperature patterns associated with the Southern oscillation. J Clim 5:577-593

Huang BH, Schopf PS, Pan Z (2002) The ENSO effect on the tropical Atlantic variability: a regional coupled model study. Geophys Res Lett 29:2039. doi:10.1029/2002GLO14872

Ineson S, Scaife AA (2009) The role of the stratosphere in the European climate response to El Niño. Nat Geosci 2:32-36

Jones, PD, Osborn TJ, Briffa KR (2003) Pressure-based measures of the North Atlantic Oscillation (NAO): a comparison and an assessment of changes in the strength of the NAO and in its influence on surface climate parameters In: Hurrell JW et al (eds) The North Atlantic Oscillation: climatic significance and environmental impact. Geophys Monogr Ser, vol 134. AGU, Washington, pp 51-62. doi:10.1029/134GM03

Jones PD, Lister DH, Osborn TJ, Harpham C, Salmon M, Morice CP (2012) Hemispheric and large-scale land surface air temperature variations: an extensive revision and an update to 2010. J Geophys Res 117:D05127. doi:10.1029/2011JD017139

Kalnay E et al (1996) The NCEP/NCAR 40-year reanalysis project. Bull Am Meteorol Soc 77:437-471

Kao HY, Yu JY (2009) Contrasting eastern-Pacific and central-Pacific types of ENSO. J Clim 22:615-632

Kim HM, Webster P, Curry J (2009) Impact of shifting patterns of Pacific Ocean warming on North Atlantic tropical cyclones. Science 325:77-80 
Knippertz P, Ulbrich U, Marques F, Corte-Real J (2003) Decadal changes in the link between El Niño and springtime North Atlantic Oscillation and European-North African rainfall. Int J Climatol 23:1293-1311

Kug JS, Ham YG (2011) Are there two types of La Nina? Geophys Res Lett 38:L16704. doi:10.1029/2011GL048237

Kug JS, Jin FF, An SI (2009) Two types of El Niño events: cold tongue El Niño and warm pool El Niño. J Clim 22:1499-1515

Kumar A, Hoerling MP (1998) Annual cycle of Pacific/North American seasonal predictability associated with different phases of ENSO. J Clim 11:3295-3308

Larkin NK, Harrison DE (2001) Tropical Pacific ENSO cold events, 1946-1995: SST, SLP, and surface wind composite anomalies. J Clim 14:3904-3931

Larkin NK, Harrison DE (2005) On the definition of El Niño and associated seasonal average U.S. weather anomalies. Geophys Res Lett 32:L13705. doi:10.1029/2005GL022738

Lee SK, Wang C, Enfield DB (2010) On the impact of central Pacific warming event on Atlantic tropical storm activity. Geophys Res Lett 37:L17702. doi:10.1029/2010GL044459

Li Y, Lau NC (2012) Impact of ENSO in the atmospheric variability over the North Atlantic in late winter-role of transient eddies. J Clim 25:320-342

Li J, Wang J (2003) A new North Atlantic Oscillation index and its variability. Adv Atmos Sci 20:661-676. doi:10.1007/BF026 90792

Li S, Hoerling M, Peng S, Weickmann K (2006) The annual response to tropical Pacific SST forcing. J Clim 19:1802-1819

Mathieu PP, Sutton RT, Dong BW, Collins M (2004) Predictability of winter climate over the North Atlantic European region during ENSO events. J Clim 17:1953-1974

McPhaden MJ, Zebiak SE, Glantz MH (2006) ENSO as an integrating concept in earth science. Science 314:1740-1745

Philander SG (1990) El Niño, La Niña, and the Southern Oscillation. Academic, San Diego

Pozo-Vázquez D, Gámiz-Fortis SR, Tovar-Pescador J, Esteban-Parra MJ, Castro-Díez Y (2005) North Atlantic winter SLP anomalies based on the autumn ENSO state. J Clim 18:97-103

Rayner NA, Parker DE, Horton EB, Folland CK, Alexander LV, Rowell DP, Kent EC, Kaplan A (2003) Global analyses of sea surface temperature, sea ice, and night marine air temperature since the late nineteenth century. J Geophys Res 108. doi:10. 1029/2002JD002670

Ren HL, Jin FF (2011) Niño indices for two types of ENSO. Geophys Res Lett 38:L04704. doi:10.1029/2010GL046031

Ren HL, Jin FF (2013) Recharge oscillator mechanisms in two types of ENSO. J Clim 26:6506-6523

Robertson AW, Mechoso CR, Kim YJ (2000) The influence of the Atlantic sea surface temperature anomalies on the North Atlantic Oscillation. J Clim 13:122-138

Ropelewski CF, Halpert MS (1987) Global and regional scale precipitation patterns associated with the El Niño/Southern Oscillation. Mon Weather Rev 115:1606-1626

Ropelewski CF, Halpert MS (1996) Quantifying Southern Oscillation-precipitation relationships. J Clim 9:1043-1059

Rudolf B, Beck C, Grieser J, Schneider U (2005) Global precipitation analysis products. Global Precipitation Climatology Centre (GPCC), DWD, Internet publication, 1-8

Shinoda T, Hurlburt HE, Metzger EJ (2013) Anomalous tropical ocean circulation associated with La Niña Modoki. J Geophys Res 116:C12001. doi:10.1029/2011JC007304

Taschetto AS, England MH (2009) El Niño Modoki impacts on Australian rainfall. J Clim 22:3167-3174
Tedeschi RG, Cavalcanti IFA, Grimm AM (2012) Influences of two types of ENSO on South American precipitation. Int J Climatol 33:1382-1400

Ting M (1996) Steady linear response to tropical heating in barotropic and baroclinic models. J Atmos Sci 53:1698-1709

Trenberth KE, Caron JM (2000) The Southern Oscillation revisited: sea level pressure, surface temperatures, and precipitation. J Clim 13:4358-4365

van Loon H, Madden RA (1981) The Southern Oscillation. Part I: global associations with pressure and temperature in northern winter. Mon Weather Rev 109:1150-1162

Wallace JM, Gutzler DS (1981) Teleconnections in the geopotential field during the Northern Hemisphere winter. Mon Weather Rev 109:784-812

Wang C, Wang X (2013) Classifying El Niño Modoki I and II by different impacts on rainfall in Southern China and typhoon tracks. J Clim 26:1322-1338

Wang X, Wang DX, Zhou W, Li CY (2012) Interdecadal modulation of the influence of La Niña events on mei-yu rainfall over the Yangtze River Valley. Adv Atmos Sci 29:157-168

Watanabe M, Kimoto M (1999) Tropical-extratropical connection in the Atlantic atmosphere-ocean variability. Geophys Res Lett 26:2247-2250

Weng H, Ashok K, Behera SK, Rao AS, Yamagata T (2007) Impacts of recent El Niño Modoki on dry/wet conditions in the Pacific rim during boreal summer. Clim Dyn 29:113-129

Wolter K (1987) The Southern Oscillation in surface circulation and climate over the tropical Atlantic, eastern Pacific, and Indian Oceans as captured by cluster analysis. J Clim Appl Meteorol 26:540-558

Wu AM, Hsieh WW (2004) The nonlinear Northern Hemisphere winter atmospheric response to ENSO. Geophys Res Lett 31:L02203. doi:10.1029/2003GLO18885

Xiang B, Wang B, Li T (2013) A new paradigm for predominance of standing Central Pacific Warming after the late 1990s. Clim Dyn 41:327-340

Xie P, Arkin PA (1996) Analyses of global monthly precipitation using gauge observations, satellite estimates, and numerical model predictions. J Clim 9:840-858

Xie F, Li JP, Tian WS, Feng J, Huo Y (2012) Signals of El Niño Modoki in the tropical tropopause layer and stratosphere. Atmos Chem Phys 12:5259-5273

Yanai M, Esbensen S, Chu JH (1973) Determination of average bulk properties of tropical cloud clusters from large-scale heat and moisture budgets. J Atmos Sci 30:611-627

Yeh SW, Kug JS, Dewitte B, Kwon MH, Kirtman BP, Jin FF (2009) El Niño in a changing climate. Nature 461:511-514

Yu JY, Zou Y, Kim S T, Lee T (2012) The changing impact of El Nino on US winter temperatures. Geophys Res Lett 39:15702. doi:10.1029/2012GL052483

Zhang WJ, Jin FF, Li JP, Ren HL (2011) Contrasting impacts of twotype El Niño over the western North Pacific during boreal autumn. J Meteorol Soc Jpn 89:563-569

Zhang WJ, Jin FF, Ren HL, Li JP, Zhao JX (2012) Differences in teleconnection over the North Pacific and rainfall shift over the USA associated with two types of El Niño during boreal autumn. J Meteorol Soc Jpn 90:535-552

Zhang WJ, Jin FF, Zhao JX, Qi L, Ren HL (2013) The possible influence of a non-convectional El Niño on the severe autumn drought of 2009 in Southwest China. J Clim 26:8392-8405 